\title{
The Dynamics of Transitions in Socio-technical Systems: A Multi-level Analysis of the Transition Pathway from Horse-drawn Carriages to Automobiles (1860-1930)
}

\author{
F. W. GEELS \\ Eindhoven University of Technology, The Netherlands
}

\begin{abstract}
This article investigates transitions at the level of societal functions (e.g. transport, communication, housing). Societal functions are fulfilled by socio-technical systems, which consist of a cluster of aligned elements, e.g. artefacts, knowledge, user practices and markets, regulation, cultural meaning, infrastructure, maintenance networks and supply networks. To understand how transitions from one socio-technical system to another come about, the article describes a conceptual multi-level perspective. The perspective is illustrated with a historical case study: the transition from horse-drawn carriages to automobiles in the USA (1860-1930). The case study shows that technological substitution approaches to this transition are too simple, because they neglect the electric tram and bicycle, which acted as important stepping stones. The case study also corrects another mistake, namely that the gasoline car won by chance from steam and electric automobiles. It will be shown that particular niches played a crucial role in this competition, as well as the wider socio-technical context. The case study deviates on three points from the multi-level perspective. These deviations are used to conceptualize a particular transition pathway, called 'de-alignment and re-alignment'.
\end{abstract}

\section{Introduction}

This article deals with transitions at the level of societal functions such as transportation, communication, housing, health care, supply of resources and supply of energy. Technology plays an important role in fulfilling societal functions, but artefacts only fulfil functions in association with human agency and social structures. Hughes ${ }^{1}$ coined the metaphor of a 'seamless web' to indicate how physical artefacts, organizations, natural resources, scientific elements and legislative artefacts are combined in order to achieve functionalities. Working from this socio-technical perspective, this article understands 
societal functions to be fulfilled by socio-technical systems. ${ }^{2}$ Socio-technical systems consist of a cluster of elements, including technology, regulation, user practices and markets, cultural meaning, infrastructure, maintenance networks and supply networks (see Figure 1 for an example for modern car-based land transportation). Transitions at the level of societal functions thus consist of a change from one socio-technical system to another.

Socio-technical systems are actively created, (re)produced and refined by several social groups, for instance, firms, universities and knowledge institutes, public authorities, public interest groups and users. Their activities reproduce the elements and linkages in sociotechnical systems. These social groups have their own vested interests, problem perceptions, values, preferences, strategies and resources (money, knowledge and contacts). This implies that transitions are multi-actor processes that involve interactions between many social groups, e.g. commercial transactions, political negotiations, power struggles and creation of coalitions.

The research question in this article is: how do transitions to new socio-technical systems come about? The existing literature offers several relevant insights, but also has shortcomings. In science and technology studies there are scholars who look at large technical systems (LTS) such as electricity networks, railroad networks, telephone systems and the Internet. ${ }^{3}$ LTS-research has developed the 'seamless web' approach, highlighting how new technical systems emerge through the gradual alignment of heterogeneous elements. In the early stages of development, these seamless webs are fragile and unstable, but as more elements are tied together they become more robust and gain momentum. However, LTS research has mainly focussed on the emergence and development of large technical systems. Much less attention has been given to the change from one system to another.

Another relevant approach is the systems of innovation literature, which investigate innovation at different analytical levels, e.g. national systems of innovation, sectoral innovation systems and regional systems of innovation. This literature shows that technical innovations emerge from interactions between firms, universities, research institutes and policy makers. An important insight is the emphasis on linkages between elements and co-evolutionary processes, but the main focus is on the functioning of systems, e.g. static or comparative analyses of the innovative performance of different countries and sectors. Not much attention has been paid to the change from one system to another. In a recent review of sectoral systems of innovation Malerba ${ }^{4}$ noted that one of the key

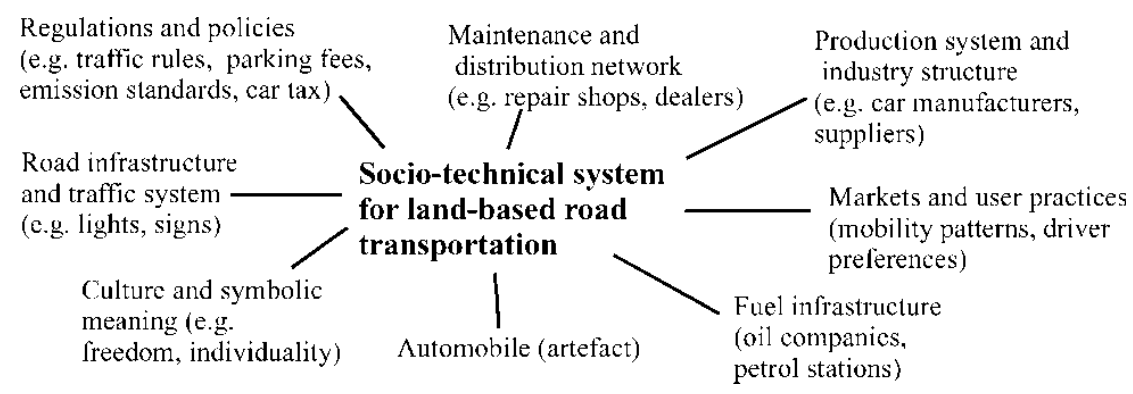

Figure 1. Socio-technical system for modern car-based transportation 
questions to be explored in depth is: 'how do new sectoral systems emerge, and what is the link with the previous sectoral system?' This question is addressed in this article.

Also relevant for the research question is the literature on 'path dependence' and 'lock-in'. In evolutionary economics David ${ }^{5}$ and Arthur ${ }^{6}$ have shown that path dependence plays an important role when two new technologies compete. When one of the technologies, by chance, gains a lead, it benefits from increasing returns to adoption and becomes dominant. Increasing returns can be caused by economies of scale, learning by using, network externalities, informational increasing returns and technological interrelatedness. ${ }^{7}$ As an illustration of path dependence theories, Nelson ${ }^{8}$ argued that the winning of gasoline automobiles in the early 20th century was simply luck:

By chance inventors tended to concentrate on it, or by chance big advances were made. However, once the gasoline engine had developed to a point where it was significantly superior to steam or electrical engines, investing time and resources to advance these other technologies came to appear a bad bet.... If the roll of the dice early in the history of automobiles had come out another way, we might today have had steam or electric cars.

As the case study in this article will show, this example is an historical and empirical simplification. The suggestion that the three different automobiles were competing from the start is too simple. It neglects aspects of the wider socio-technical context that were more favourable to gasoline cars than to electric and steam automobiles (in particular, fuel infrastructure, cultural values and maintenance network). It also neglects the fact that the different automobiles were used in different niches and did not compete much.

A strong point of economic path dependence theories is that they point to mechanisms that contribute to lock-in and give winning technology stability. Other disciplines have added more reasons why existing socio-technical systems are characterized by stability and lock-in. Established systems may be stabilized by legally binding contracts. ${ }^{9}$ Cognitive routines make engineers and designers look in particular directions and not in others. ${ }^{10}$ This can make them 'blind' to developments outside their focus. Core capabilities can thus turn into core rigidities. ${ }^{11}$ Firms have sunk investments in machines, skills and knowledge, which they do not want to lose. Hence, it is difficult for established firms to switch to competence destroying breakthroughs. ${ }^{12}$ Systems are also stabilized because they are embedded in society. People adapt their lifestyles to them, favourable institutional arrangements and formal regulations are created, and accompanying infrastructures are set up. The alignment between these elements leads to technological 'momentum'. ${ }^{13}$ The importance of these alignments between heterogeneous elements is highlighted in concepts such as the techno-institutional complex ${ }^{14}$ and techno-economic networks ${ }^{15}$. These approaches highlight aspects of stability of existing systems, but none of them address the issue of transition from one system to another. Path-dependency literatures help us understand lock-in, but how can we understand 'lock-out'?

Another approach to transitions can be found in the technological substitution literature. Grübler ${ }^{16}$ and Nakićenović ${ }^{17}$ proposed to understand long-term transitions as a technological substitution process. Their basic assumption is that the replacement of an old technology by a new technology proceeds along the logistic substitution curve: $f /(1-f)=\mathrm{e}^{(a . t+b)}$, in which $t$ is the independent variable representing some unit of time, $a$ and $b$ are constants, $f$ is the fractional market share of the new competitor 
and $(1-f)$ is the fractional market share of the old one. They illustrated their approach by matching historical data on logistic curves. Figure 2, for instance, portrays the replacement of (urban) riding horses by cars in the USA.

Substitution approaches suggest a particular kind of dynamic, namely a competitive struggle between old and new technologies. The emergence of new technologies is assumed to go at the expense of old technologies. For instance, Grübler ${ }^{18}$ claims that 'the car industry grew initially by replacing horses'. Nakićenović ${ }^{19}$ writes, 'In the US the first horseless carriage posed an alternative to the horse-drawn buggies and wagons. Especially as a commercial vehicle, the motor car offered many advantages, e.g. increased radius of local transportation.' In this conceptualization, old and new technologies compete right from the start. The case study in the third section of this article will show that the first automobiles were not used for instrumental transportation purposes, but in niches related to pleasure and excitement. In these niches the first cars did not compete with horses, meaning that Grübler's and Nakićenović's claims about early cars are incorrect. Ex-post curve fittings of substitution processes thus run the danger of misrepresenting the historical reality, especially in the early phases of new technologies. Another criticism is that logistic curve approaches are very aggregate. Representations such as Figure 2 suggest that the number of horses declined because of automobiles, but the case study in this article will show that urban horses were first replaced by the electric tram and only later by the automobile. The danger of aggregate, ex-post representations is that 'intermediate' technologies, such as the electric tram and also the bicycle, disappear from view. Another drawback is that the substitution approach only looks at technologies and markets, and neglects other aspects such as policies and regulations, user preferences, infrastructures, cultural and symbolic meanings,

1000 Uhito

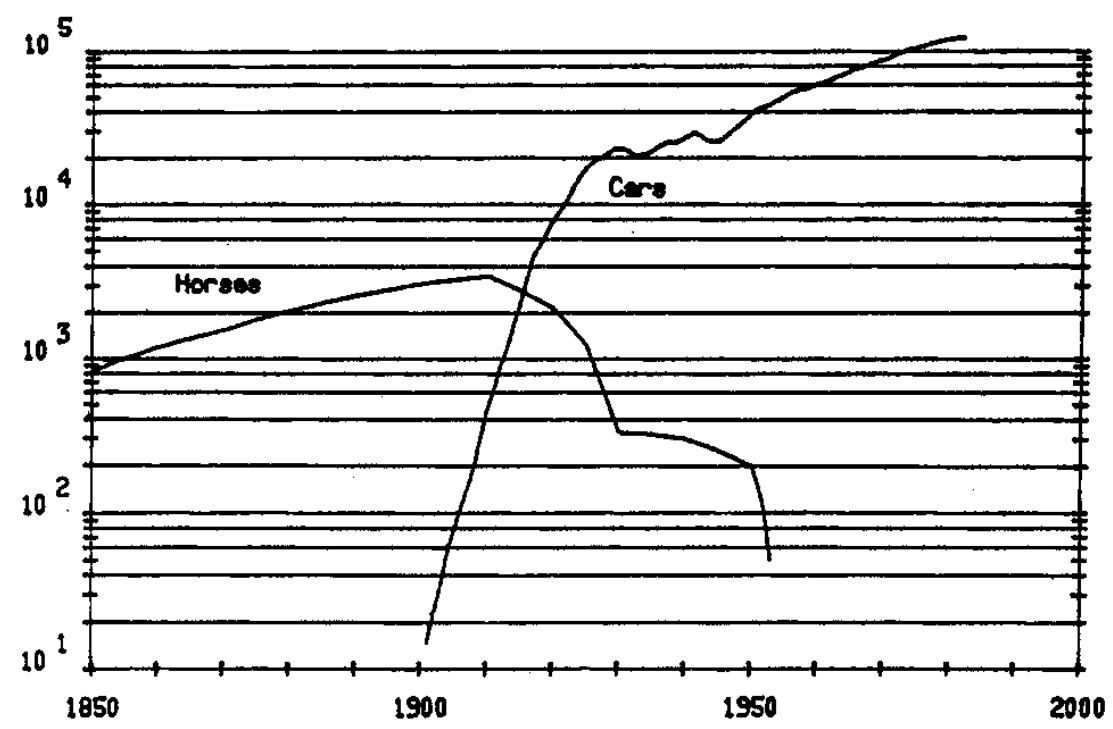

Figure 2. Population of road horses and number of cars in USA. Source: Nakićenović (Ref. 17, p. 320) 
but such aspects are usually important in transitions, as will be shown in the third section (Case Study).

One conclusion from this discussion is that disciplinary approaches offer interesting bits and pieces for understanding the dynamics of transitions, but also have drawbacks and make limited cross-sections of socio-technical systems. Another conclusion is that the automobile transition is often used as an example to illustrate particular theoretical points. However, these examples are often based on too simple representations. Hence, this article has three aims, elaborated in different sections. The first aim is to describe a conceptual multi-level perspective on transitions (second section) and illustrate it with a historical case study: the transition from horse-drawn carriages to automobiles in the USA (third section). The second aim is to correct some mistakes that exist about this transition. The case study not only looks at horses and automobiles, but also highlights the role of electric trams and bicycles, making the transition more complex than in the technological substitution approach. The case study will also emphasize the importance of niches in the emergence of new technologies, thus engaging in a debate with path dependence theories. The third aim is to further refine the multi-level perspective by theorizing about three ways in which the case study deviates from the predicted pattern (final section). The main refinement is to develop a particular transition pathway within the multi-level perspective, called 'de-alignment and re-alignment'.

\section{Conceptual Multi-level Perspective}

This section briefly outlines the multi-level perspective on transitions, which has been described more elaborately elsewhere. ${ }^{20}$ The perspective distinguishes three conceptual levels: niche, socio-technical regime, socio-technical landscape. The basic ontology behind this perspective stems from the sociology of technology, where three interrelated dimensions are important: (i) socio-technical systems, i.e. the tangible elements needed for fulfil societal functions, (ii) social groups who maintain and reproduce the elements and linkages of socio-technical systems, (iii) rules (understood as regimes) that guide and orient activities of actors and social groups (see Figure 3).

Before turning to the multi-level perspective, these dimensions and their inter-relations will be described. The elements and linkages of socio-technical systems do not exist autonomously, but are created, (re)produced and refined by social groups. Actors in these social groups act in the context of social structures and formal, normative and cognitive rules. Rules form a coordinating context that guides and orients action. On the other hand, rules are reinforced and changed through action and enactment. Rules do not exist

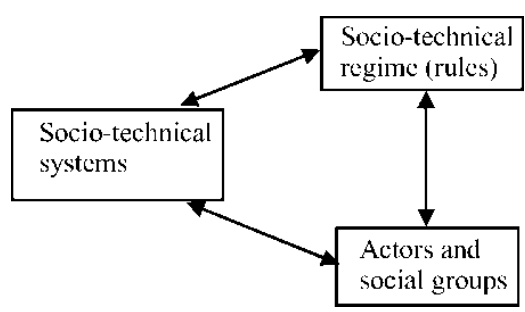

Figure 3. Three interrelated analytic dimensions. Source: Geels (Ref. 2, p. 903). 
individually, but are linked together in semi-coherent sets of rules, called regimes. Nelson and Winter ${ }^{21}$ coined the term 'technological regimes', which referred to the cognitive routines (e.g. search heuristics) that are shared in a community of engineers and guide engineers in their R\&D activities. Through their coordinative effects, technological regimes create relative stability at the sectoral level and lead to incremental innovation along technical trajectories. Rip and $\mathrm{Kemp}^{22}$ have widened the definition of technological regimes from cognitive routines to the wider sociological category of 'rules', which involve problem agendas, guiding principles, rules of thumb, search heuristics, standards, relevant government regulations and representations of user preferences. The technological regime concept has been further widened to 'socio-technical regimes' that include additional social groups besides engineers, for instance, scientists, users, policy makers and societal groups. ${ }^{23}$ Although these social groups have relative autonomy, they also interact and form networks with mutual dependencies. Hence, activities of social groups are aligned to each other. This inter-group coordination is represented with the concept of socio-technical regimes.

The socio-technical regime forms the meso-level in the multi-level perspective (MLP). Through providing orientation and coordination to the activities of relevant social groups, socio-technical regimes account for the stability of existing socio-technical systems. The discussion of the path dependence literature in the Introduction provided several examples of rules that contribute to the stability of existing socio-technical systems, e.g. legally binding contracts, cognitive routines, core capabilities and competences, lifestyles and user practices, favourable institutional arrangements and regulations. Existing systems are further stabilized by social relationships. Actors and organizations are embedded in interdependent networks, which represent a kind of 'organizational capital' and create stability through mutual role expectations. Organizational commitments and vested interests of existing organizations also contribute to the stability of existing socio-technical systems. ${ }^{24}$ Furthermore, powerful incumbent actors may try to suppress innovations through market control or political lobbying. Industries may also create special organizations to lobby on their behalf, e.g. industry associations or branch organizations. ${ }^{25}$ The material aspects of socio-technical systems also contribute to stability, because of sunk investments. Once artefacts and material networks are in place, they are not easily abandoned and acquire a logic of their own. ${ }^{26}$ So, for many reasons, existing socio-technical systems are characterized by stability. This stability is not inertia, but dynamic stability, meaning that innovation still occurs but is of an incremental nature.

Because of the stabilizing mechanisms, it is difficult to create radical innovations within socio-technical systems. So how do radical innovations emerge? Scholars in sociology of technology and evolutionary economics have highlighted the importance of niches as the locus of radical innovations. Because the performance of radical innovations is initially low, they cannot immediately compete on mainstream markets in the regime. Niches act as 'incubation rooms' for radical innovations, nurturing their early development. ${ }^{27}$ Niches may have the form of small market niches, with specific selection criteria that are different from the existing regime. Or they may have the form of technological niches, where resources are provided by public subsidies or private strategic investments. These can be $\mathrm{R} \& \mathrm{D}$ projects, but also experimental projects, involving heterogeneous actors, e.g. users, producers, public authorities. ${ }^{28}$ Evolutionary economists have highlighted the point that niches provide a trickle of resources that enable a new technology to survive and develop in relative isolation. ${ }^{29}$ Sociologists of technology have added the 
importance of socio-cognitive processes, in particular the build up of social networks and the coordination of activities by shared rules and perceptions. ${ }^{30}$ In niches there is little stability in the seamless web and much uncertainty. The social networks around new technologies are small and the rules are diffuse and unclear. Actors work in different directions, exploring different trajectories. Niches are important, because they provide space for learning processes on several dimensions, e.g. technology, user preferences, regulations, infrastructure and symbolic meaning. That way the seamless web of an innovation can be further articulated. Niches also provide space to build social networks that support innovations, e.g. lobby groups, user associations and new industry networks.

The macro-level in the MLP is formed by the socio-technical landscape, which refers to aspects of the wider exogenous environment that affect sociotechnical development. The metaphor 'landscape' is used because of the literal connotation of 'hardness' and to include the material aspect of society, e.g. the material and spatial arrangements of cities, highways and electricity infrastructures. ${ }^{31}$ Landscape form 'gradients' for action from which it is hard to deviate. They are beyond the direct influence of actors and cannot be changed at will.

The relationship between the three conceptual levels can be understood as a nested hierarchy. The key point of the multi-level perspective (MLP) is that transitions come about through the interplay between processes at different levels. ${ }^{32}$ Several phases are distinguished in transitions. ${ }^{33}$ In the first phase, radical innovations emerge in niches, often outside or on the fringe of the existing regime. The seamless web of the early innovations is unstable and fragile. There are no stable rules (e.g. dominant design) and there may be various technical designs competing with each other. Actors improvise, engage in experiments to work out the best design and find out what users want. The networks that carry and support the innovation, are small and precarious. The innovations do not (yet) form a threat to the existing regime.

In the second phase the new innovation is used in small market niches, which provide resources for technical development and specialization. The new technology develops a technical trajectory of its own and rules begin to stabilize (e.g. a dominant design). Users build up experience with the new technology, articulate their preferences and may form user clubs to do lobbying work, but the innovation, which is used in specialized market niches, still forms no major threat to the existing regime that is entrenched in many ways (e.g. institutionally, organizationally, economically and culturally). New technologies may remain stuck in these niches for a long time (decades), when they face a mis-match with the existing regime. ${ }^{34}$ As long as the regime remains stable, niche innovations have little chance to diffuse more widely.

The third phase is characterized by wider breakthrough of the new technology and competition with established regime. On the one hand, this depends on internal drivers in the niche. Improvements in the price/performance ratio are an important driver, for instance as a result of increasing returns to adoption (see the Introduction). Another important driver is that powerful actors support the innovation and use their financial, organizational or political capital to stimulate its development and help overcome resistance from other social groups. On the other hand, external circumstances at regime and landscape levels are also crucial in this third phase, creating windows of opportunity for novelties in niches. These windows emerge when tensions occur between elements in the socio-technical regime, i.e. when the activities of social groups become mis-aligned. An important reason for these tensions is that social, cultural or economic changes at the landscape level 
put pressure on the regime. Another reason is that the existing regime is plagued by increasing internal problems that cannot be solved by incremental improvements. The regime problems may be exacerbated by tougher regulatory measures and changing user preferences. The multi-level perspective emphasizes that both internal nichedynamics and external developments at regime and landscape level are important for wider breakthrough and diffusion (see Figure 4).

The breakthrough from niche- to regime level does not take place at once, but through a sequence of steps. While the innovation is initially used in specialized technological or small market niches, it captures increasingly larger market niches. Wide diffusion thus occurs through a process of niche-accumulation (see Figure 5). During this process, market shares of the new innovation increase and more elements are created to support the innovation, e.g. infrastructures, regulations, cultural enthusiasm and user practices. The seamless web becomes increasingly stable and gains momentum, because an increasing number of elements is linked together.

As the new technology enters mainstream markets it enters a competitive relationship with the established socio-technical regime. In the fourth phase this leads to replacement, something that is accompanied by wider socio-technical changes. Replacement often happens in a gradual fashion, because the creation of a new socio-technical regime takes time. The new system may eventually influence wider landscape developments.

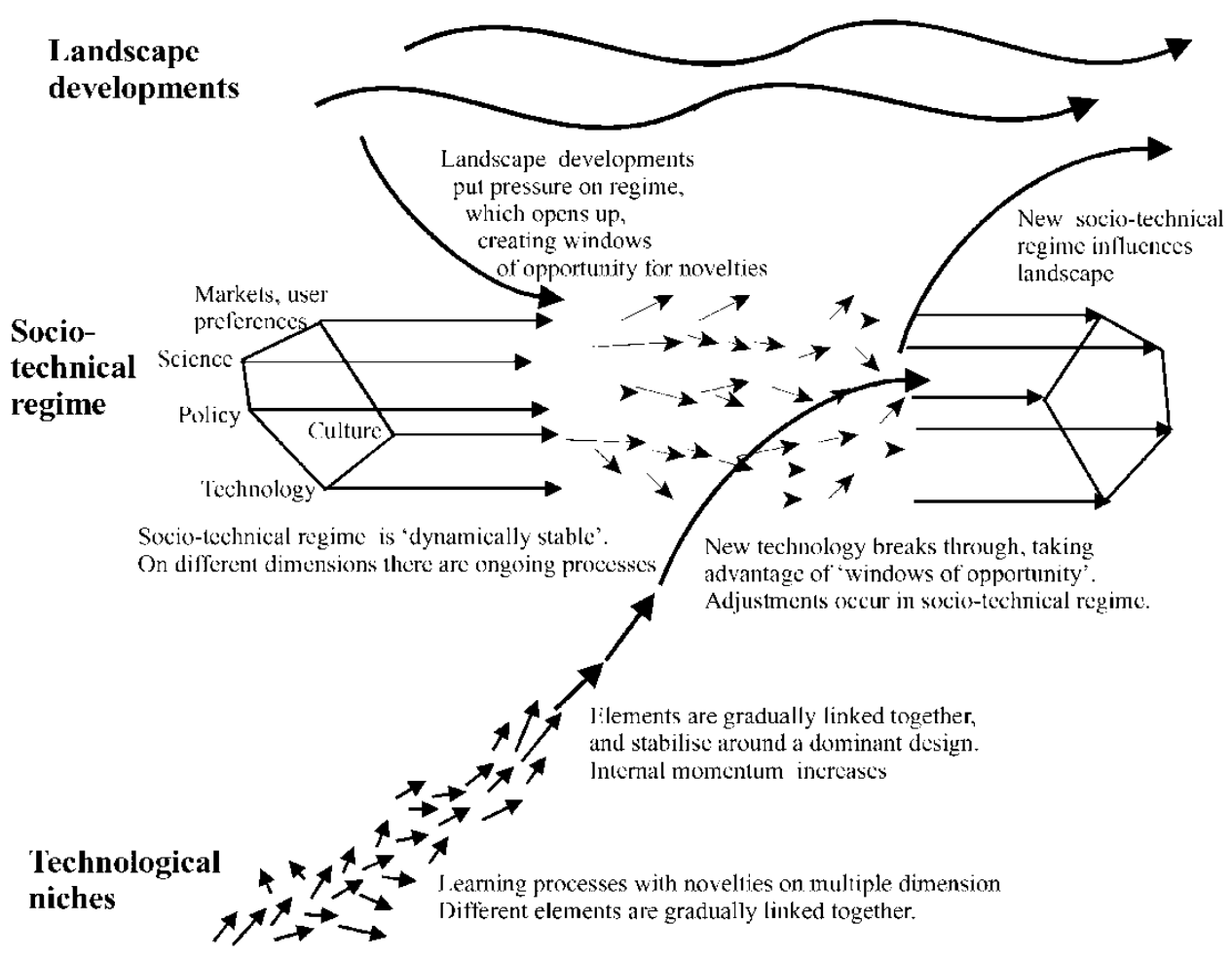

Figure 4. A dynamic multi-level perspective on transitions. Source: Geels (Ref. 20, p. 87) 


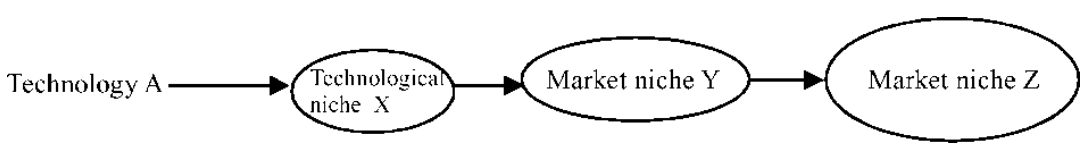

Figure 5. Diffusion as a process of niche-accumulation. Source: Levinthal (Ref. 29, p. 243)

An important aspect of the multi-level perspective is to do away with simple causality in transitions. There is no simple 'cause' or driver. Instead, there are processes at multiple dimensions and levels simultaneously. Transitions come about when these processes link up and reinforce each other ('circular causality').

The multi-level perspective in Figure 4 works from the 'outside in', describing and mapping the entire long-term process. With its emphasis on the alignment of processes at different levels it may seem mechanical and linear, but these impressions disappear when actors and social groups are added. As represented in Figure 4, processes in socio-technical regimes and systems are the outcome of perceptions and (inter)actions of actors and social groups. These social groups try to navigate a transition, find their way through searching and learning, interact in power struggles, controversies and debates. The 'outside in' approach is thus complemented with an 'inside out' approach. Because the linkages between processes at different levels are made by actors in their cognitions and activities, the dynamics are not mechanical, but socially constructed. The dynamics are not linear, because perceptions and strategies of actors change over time. Transitions are complex processes that cannot be overseen or steered from one viewpoint. They are emergent outcomes of interactions between social groups with myopic views and differing interests, strategies and resources. Some groups with vested interests have things to lose, others hope to gain certain advantages. Hence transitions are contested and different groups struggle, negotiate and form coalitions. So the overall dynamic is not a smooth and linear process, but a crooked process, proceeding with accelerations and slowing down.

\section{Case Study: From Horse-drawn Carriages to Automobiles in American Urban Passenger Transport (1860-1930)}

The multi-level perspective sketched above has been illustrated with case studies about the transition from sailing ships to steamships, ${ }^{35}$ the ongoing transition in Switzerland from industrialized agriculture to integrated production and organic farming, ${ }^{36}$ the implementation of manure digestion and co-combustion in the Dutch electricity regime ${ }^{37}$ and the transition from manual to mechanized cargo unloading in ports. ${ }^{38}$ This section presents a case study that partly replicates the MLP and partly deviates from it. The case study is the transition from horse-drawn carriages to automobiles in American urban passenger transport (1860-1930). This transition is often portrayed as a substitution process in which horses were replaced by cars (see the Introduction). The case study in this section will show that historical dynamics were more complex. The focus in the case study is on the societal function of urban passenger transport, because new transport technologies (bicycles, electric trams and automobiles) were first developed and used in urban areas, and then spread wider. The description focuses on America, because this country led the way in the shift to automobiles. The focus is on passenger transportation, not on 
freight, because more secondary sources were available. The case-study is not intended primarily to unveil new historical facts, but to replicate and refine the conceptual perspective. Hence it is based on secondary, published material from the history of technology, transport history and urban history. The time period of the case study is $1860-1930$. This means the analysis starts in the period when horse-based transportation was dominant and innovative, and had multiple forms, e.g. omnibus, horse tram, horse taxi (four-wheel hackney or two-wheel cabriolet), horse-drawn wagon for freight transport, and private horses and carriages. The case study ends in the 1930s, when automobiles had established themselves as the dominant transportation mode for the middle classes, and were supported by powerful social groups. After the Second World War the car would diffuse more widely to the working classes. The second graph in Figure 6 shows that the diffusion of automobiles consists of two S-curves, the first from 1900 to 1940 and the second from 1950 to 1990. The case study focuses on the first S-curve. Although not everybody owned a car in the 1930s, it was by then a widely shared opinion that the automobile was the way forward.

The case study has two major aims. The first aim is to illustrate the usefulness of the concepts in the MLP and the importance of linkages between levels. In the late 19th century American society was in flux, with major changes occurring on political, social and cultural dimensions. So it is expected that landscape changes will play a prominent role in the case study. The case study will also show the importance of niches for the emergence of radical innovations. Special attention will be given to the emergence of automobiles, because other authors often refer to it in a too simplistic way (see the Introduction). The case study also highlights the 'inside out' approach, and the coalitions and struggles between social groups (e.g. horse tram companies, policy makers, local residents and automobile clubs). A second aim is to provide material to refine the MLP. On three points the case study deviates from the MLP: (i) the existing regime becomes unstable early in the transition, (ii) there are multiple technologies involved, instead of only 'new' and 'old' technologies, (iii) there is an overall pattern of widening up, prolonged co-existence of multiple technologies and narrowing down to one technology (the automobile). These deviations form the basis for conceptual refinement of the multi-level perspective in the concluding section.

The empirical description is organized in four sub-sections that follow the four phases of the multi-level perspective. In each period, dynamics at landscape-, regime- and nichelevel are described and summarised at the end of each sub-section.
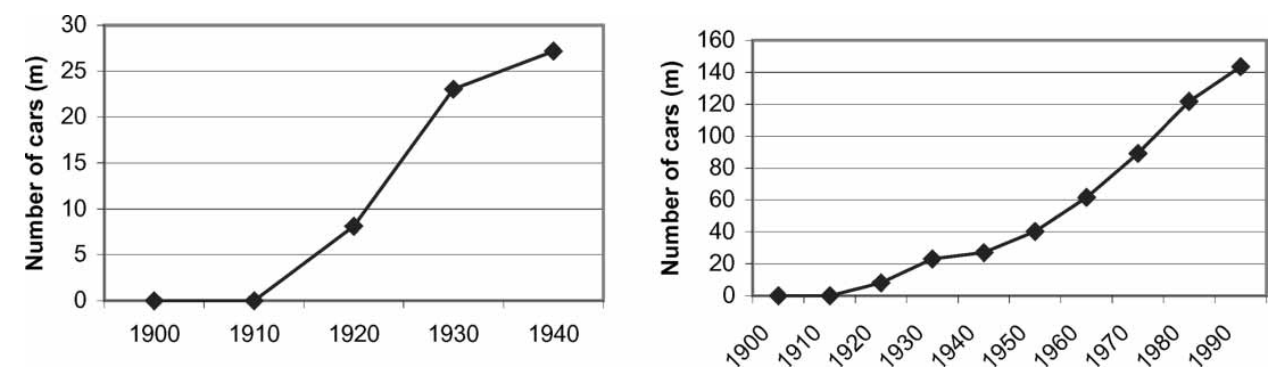

Figure 6. Diffusion curve in US automobile registrations, 1900-1940 and 1900-1990. Source: Based on data from Mowery and Rosenberg (Ref. 39, p. 50) 


\section{Expansion of Horse-based Transportation (1860-1885)}

In the second half of the 19th century, industrialization and urbanization were two important landscape developments. The emergence of steam power enabled a relocation of factories to cities, where railroads provided cheap coal. In tandem with this relocation, people increasingly moved to cities, which, as a result, expanded in size.

The landscape change of urbanization created pressure on the urban transport regime. The expanding cities led to longer travel patterns, which were harder to do by foot. Hence, innovations were developed in the urban horse-based transport regime, mainly for middle- and high classes. Middle-classes began to use the omnibus, a rectangular 'box on wheels', drawn by horses and carrying between 15 and 25 people. New York had 70 omnibuses in 1830, 350 in 1849 and a peak of 683 in $1854 .{ }^{40}$ Upper classes had their own private carriage or used horse-drawn taxis. An important innovation was the horse tram: horse-drawn carriages on railroads. This way a horse could pull a vehicle at $30 \%$ higher speed and haul $100 \%$ more passengers. ${ }^{41}$ They replaced omnibuses on busy routes in the 1850 s and 1860 s and became the first urban mass transportation mode. In 1880 there were around 19,000 horse trams in America, operating on an infrastructure of $4800 \mathrm{~km} .{ }^{42}$ Large horse tram companies operated fleets of thousands of horses, housed in large stables. The large stables also entailed risks, in particular disease and fire. Hence cities created a wave of stable regulations. Thousands of stable boys, blacksmiths and carriage manufacturers were involved in the feeding and stabling of horses, and maintaining the carriages. Feeding and stabling accounted for more than $50 \%$ of the tramway companies' costs. ${ }^{43}$ City authorities formed sanitation departments to clean the streets of horse manure. In sum, an entire regime was created around horse-based transportation, involving many social groups. This regime expanded until the end of the 19th century. Horse trams, carriages, wagons and pedestrians all mixed in the streets. Although streets were used for transportation, they also functioned as social meeting places for play, social talk and street vending. Streets were unpaved dirt roads or covered with rough cobblestones. Horse-drawn vehicles experienced cobblestones as problematic, because it damaged the wheels. Hence, there was pressure to smoothen street surfaces. A first wave of street improvements began after the Civil War (1861-1865), using macadam (alternating layers of stones, large ones at the bottom and smaller ones on top). The street improvements encountered setbacks in the early 1870 s, because of financial scandals, overspending and corruption. Road improvement was also hindered by local residents, who traditionally had the power to administer their streets. Local residents had no interest in smoothening street surfaces, because for them traffic was more of a hindrance than a benefit. Many residents felt that smooth road pavements were for the rich and not for average citizens. ${ }^{44}$

Various new transport options emerged in particular niches. The earliest bicycles were developed in the 1830 s as toys for the upper classes. At the end of the 1860 s a new application domain was articulated: bicycle racing on racetracks. The users were athletic young men, wanting to prove their skill, courage and strength. ${ }^{45}$ These user preferences gave rise to the Penny-farthing that had a very large front wheel, which enabled high speed, but was unstable. Because the bicycle functioned as an adventure machine, ${ }^{46}$ this instability was not seen as a problem. Another radical novelty were electric automobiles. The first experiments with these vehicles date back to 1842, but they suffered from weak electric motors and heavy batteries. There were also attempts to use steam engines for road transportation. 
Steam buses were commercially used in London in the early 1830s, but steam engines were heavy and cumbersome, and prone to boiler explosions. In the 1860s steel made possible new boiler designs and lighter steam automobiles. In America, this resulted in a new design trajectory: smaller and lighter steam vehicles. Roper, for instance, built a light (650 pound) steamer in 1863, capable of doing 20 miles per hour. In the 1860s and 1870s, steam automobiles were used as fascinating novelties at racetracks and in circus parades. ${ }^{47}$ Although further technical improvements were made in the 1870 s and 1880 s, steam automobiles did not catch on, because of public resistance and regulation. The regulators reflected public opinion when they banned steamers because of their speed, smoke, steam exhaust and potential for explosion. ${ }^{48}$ Other niche innovations were formed by mechanical ways to propel trams. Because horses were expensive, horse tram companies had an interest in alternative propulsion options. One option was steam, used either in the form of steam engines or as cable cars, i.e. trams that were pulled by underground cables powered by a central steam engine. Another technical option was the use of electric motors and wires. Electric trams formed a technological niche between 1879 and 1888, when they were tried out at expositions and exhibitions.

In terms of the multi-level perspective there was some interaction in this period between landscape changes and regime dynamics, in particular the expansion of cities that created pressure on the transport regime, which responded with incremental innovations such as the omnibus and horse tram. Radically new transport options (bicycles, electric vehicles and steam automobiles) were developed for particular niches. These experimental novelties were not meant for practical transport purposes, but for fun and entertainment. They formed no threat to the existing regime. Only the development of alternative options to propel trams had some potential, because they might provide a solution to the high-cost problem of horse trams.

\section{Heating up and Fluidity in the Urban Transportation Domain (1885-1903)}

At the end of the 19th century America was a society in flux. There were many external landscape changes that influenced dynamics in the regime and the niches. Some landscape developments of the earlier period continued, such as industrialization and the growth of industrial cities. A new landscape development was immigration. In the 1880s and 1890s about 600,000 people annually entered America. ${ }^{49}$ In the growing cities, immigrants and working class people lived in crowded and filthy slums. Cities came to be seen as filthy, unhealthy and dangerous. In reaction, many middle-class American families began to develop a cultural preference for suburban living, something that was seen as a haven from the tumultuous society. ${ }^{50}$ The middle class expanded in this period, as the number of salaried employees, managers, technicians, clerks and engineers grew in corporations and government. The new middle class had more money and more work-free leisure time, to be enjoyed in the form of entertainment. This led to a new popular culture, where values such as entertainment, excitement, fun and active sporting became highly valued. Another cultural landscape development was the increasing attention in public debates for health and hygiene. The emerging hygiene movement and new health professionals thought that the abundance of decaying organic filth filled the air with poisonous vapours, miasmas, which caused epidemic diseases. Light and fresh air were thought to improve public health. Hence, parks were built to function as the lungs of the city. Another cultural macro-development was societal enthusiasm about electricity, which 
was seen as the symbol of a new age. This cultural enthusiasm stimulated investors to put their money in electric trams, electric light, and electric automobiles. A landscape change on the political dimension was the expansion of public administration. Both on local, state and federal level, public authorities acquired more responsibilities and public tasks. The period between 1890 and World War I is often characterized as the 'Progressive Era'. Policy makers and reformers aimed to end political corruption and address poverty and urban problems. Sub-urbanization was seen as a way to reduce urban problems. To facilitate commuting between home and work, policy makers and reformers encouraged the spread of electric trams and engaged in street improvements. ${ }^{51}$ Cities also linked individual parks through a series of 'parkways', climaxing in the Parkway movement in the 1890s. This was part of a wider trend to segregate and reform public space. ${ }^{52}$ Streets were cleaned up, selling on the street was forced off thoroughfares, and recreational activities were pushed into parks and playgrounds.

The landscape development of urbanization stimulated the expansion of horse-drawn transport. Between 1870 and 1900 the use of horses for transportation grew exponentially for horse trams, freight wagons, taxis. ${ }^{53}$ The landscape development of creating parks and parkways influenced the transport regime, in the sense that it helped to give carriage driving a new function. As the upper classes drove their carriage in parks at evenings and in the weekend, driving in the open air became associated with fun. It also stimulated the mobility practice of high speed. Riding with carriages on parks and parkways gave rich people the exciting experience of high speed. ${ }^{54}$ But the wider landscape developments also create pressure on the urban transport regime, leading to problems and tensions. The first problem was high cost for tram companies, related to the feeding and stabling of horses. Hence horse tram companies became more interested in alternative options to propel trams, e.g. with steam or electricity. The second problem was congestion. Streets in most cities were not built to accommodate high traffic flows. Horses and wagons occupied much street space, and different transport modes operated at different speeds, hindering the overall flow. A few slow vehicles could create major traffic jams. The third problem was safety, related to kicking and biting of horses or being overrun by carriages. The fourth problem was pollution. Horses produced a huge amount of manure, over 150,000 tons annually in New York, ${ }^{55}$ but stories that streets were covered in metres of manure are exaggerated. Although the amount of manure was a problem, there was also increased sensitivity for the matter, something that was related to the wider hygiene movement and cultural attention to health and hygiene. Manure was thought to provide a likely vector for bacilli that caused respiratory infections. Hence, horses acquired a negative symbolic meaning in public debates. In sum, the expansion of horse-based transport regime created major problems in technical, economic and cultural dimensions.

The regime problems created windows of opportunity for the diffusion of transportation technologies that were developed for special niches in the previous period. Some of these technologies also linked up favourably with external landscape changes, increasing their viability. Some of these options developed rapidly from niche to alternative transport regime, in particular the electric tram. Others conquered market niches and enjoyed high cultural enthusiasm, in particular, bicycles and automobiles. These transport options, their relationship to landscape changes and the further socio-technical changes they triggered, will be discussed below, as will the struggles concerning road pavements that divided the city.

The first market niche for electric trams was created in 1888 by Frank Sprague in hilly Richmond, where horses had difficulty to draw trams uphill. The wider diffusion of 
electric trams was very rapid. In 1890, $16 \%$ of American street railways were electrified, about $70 \%$ were horse or mule powered and $14 \%$ consisted of cable cars or steam railways. By $1902,97 \%$ of American street railways were electric. ${ }^{56}$ So, with regard to tram propulsion, electric motors replaced horses in 14 years. Horses were, of course, still used to pull taxis, private carriages and freight wagons. The electric tram quickly developed into a new transport regime, because of several reasons. One reason was technical and economic advantage. The electric tram was about twice as fast as the horse tram (12 mph vs 6 $\mathrm{mph}$ ) and it eliminated the problem of horse manure. Operational costs were lower, reducing the cost per car-mile from 8-11 cents for horsepower to 1.5 cents for electric power. ${ }^{57}$ A problem for the electric tram was the high initial costs for the creation of a new infrastructures (e.g. electricity wires, stronger rails) and the purchase of electric trams. However, as a result of scale advantages and learning by doing, the price of electric trams decreased over time, from US $\$ 4500$ in 1889 to $\$ 750$ in $1895 .{ }^{58} \mathrm{~A}$ second reason was that powerful social groups supported the electric tram. Horse tram companies were eager to replace their expensive horses by cheaper electric trams, although switching costs created some problems. Real estate promoters invested in tram lines because they increased the value of their land. ${ }^{59}$ Electric light companies promoted the electric tram, because it provided an additional electricity market that perfectly complemented their night-time light market. Local authorities and urban reformers also promoted the tram as a means to enhance sub-urbanization. In addition the electric tram linked up well with the general cultural enthusiasm for electricity and its uses. Because of this enthusiasm, investors were willing to put money into trolleys and help horse tram companies make the switch. As the use of electric trams spread across the country, it had wider socio-technical knock-on effects. First, the trolley contributed to sub-urbanization by creating an urban system of mechanized mass transit, that was relatively cheap-5 cents a trip with free transfers. ${ }^{60}$ The trolley enabled people to travel between work and home. Second, trolleys stimulated tourism for lower classes, e.g. day trips, picnics or walks in the countryside, particularly when local tram networks were connected to each other after 1900, resulting in an interurban transport network. ${ }^{61}$ The popularity of tourism created new transport patterns that would later link up with automobiles. Third, trolleys stimulated a cultural change in the perception of the function of streets. Streets were increasingly defined as transport arteries, rather than as social meeting places. Fourth, the trolley contributed to a cultural change in the attitude of local residents with regard to high-speed vehicles in the street. This did not happen overnight. Early trolleys encountered protests, because they caused accidents and killed people. ${ }^{62}$ In 1900 , the Popular Science Monthly noted:

Prejudice against mechanically-propelled vehicles has gradually worn away, probably because of the introduction of cable and trolley cars, and at the present the majority desire to see the substitution of mechanical for animal power. ${ }^{63}$

A new transport option that enjoyed high cultural popularity for recreational purposes was the bicycle. The introduction of the safety bicycle (1885), based on two wheels of the same size and a tubular frame, made the bicycle accessible for wider user groups such as women and elderly men, for whom stability, safety and easy riding were important selection criteria. ${ }^{64}$ The mobility practice of driving for fun and entertainment, first articulated with horse-drawn carriages in parks, was further developed with bicycles. In the 1890s 
'touring' with the bicycle became very popular, because it linked up with wider cultural developments at the landscape level, e.g. the cultural values of recreation and fun, but bicycles also linked up with the health movement and cycling was seen as 'practising hygiene'. The popularity of cycling led to the bicycle craze of 1895-1896, followed by a collapse of the world market in 1897. The bicycle industry was faced with over-production and prices went down, bringing the bicycle into reach of labourers. Another effect of the market crisis was that many bicycle producers diversified their activities to developing automobiles. ${ }^{65}$ As bicycle use spread, it had wider socio-technical knock-on effects. First, experience with the bicycle gave rise to the articulation of new user preferences and mobility practices. Individual driving and flexible driving were two new functionalities, celebrated in the mobility practice of touring. Another new element was the creation of bicycle clubs, which developed into lobby organizations for better roads (the Good Roads movement). Third, bicycles led to the further articulation of production technologies, e.g. interchangeability of parts and automated manufacturing methods using special-purpose machine tools. The bicycle industry also introduced new elements in metalworking, in particular sheet metal stamping and electric resistance welding. ${ }^{66}$ These techniques facilitated quantity production and were later used in car manufacturing.

Another important development in urban transport was the change in the road pavement. Dirt roads and macadam pavements became unsatisfactory, because heavy wagons tore them apart. The 1890s were characterized by a new wave of street improvements, using concrete and asphalt. These street improvements involved a power struggle between local residents and middle-class reformers. ${ }^{67}$ Local residents resisted road improvements, because they saw roads as social meeting places, not as transport arteries. This power struggle was influenced by an external landscape development, the expansion of public administration and the transfer of power and responsibilities to public authorities. The traditional right of local residents to administer their streets was gradually eroded and transferred to local authorities. Middle class reformers increasingly acquired powerful positions such as municipal engineers, city planners, reform-minded politicians and judges. In these positions, they were able to implement legal changes in the administration of streets and push through their ideas about the function of streets. ${ }^{68}$ As a result, by 1900 , American cities had built hundreds of miles of parkways and boulevards, paved with macadam, concrete or asphalt.

In this period, automobiles emerged as a radically new transport option. This niche innovation triggered much societal enthusiasm, because it linked up with several wider landscape developments. Early automobiles were constructed by adding petrol engines, steam engines and electric motors to existing coaches and tricycles. Light steam automobiles were improved, using petroleum instead of coal to heat the boilers. Serpollet's flash boiler (1889) made it possible to start steamers within $5 \mathrm{~min}$. Electric vehicles were improved, using lighter Fauré batteries developed in 1881. Although the first electric vehicle was a light carriage (1881), heavy carriages were easier to electrify, because they could better carry the weight of batteries. Batteries powered small electric motors placed close to the wheels. Electric vehicles borrowed the mechanical 'controller' from the electric tram, which allowed easy starting, acceleration and gearing. Electric cars were considered clean, quiet, reliable and easy to handle. With regard to gasoline cars two trajectories were followed. The first trajectory was to add gasoline engines to bicycles and tricycles, e.g. Benz' car of 1885 . The second trajectory was to add gasoline engines to carriages, e.g. Daimler in 1885 (Figure 7). 


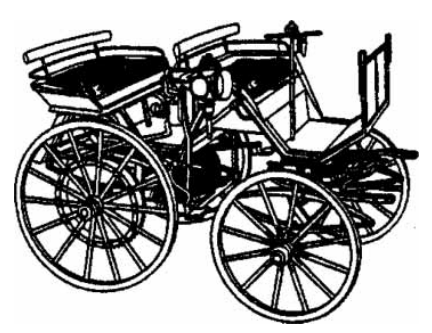

Figure 7. Daimler's horseless carriage from 1885. Source: Georgano (Ref. 69, p. 10)

Gasoline cars had to overcome several technical bottlenecks, because of specific characteristics of internal combustion engines (ICE). An ICE cannot deliver power from standstill, because energy is required to start the movement of pistons, connecting rod and crankshaft. During starting the engine needs to be uncoupled from the wheels, to prevent stall. Hence, a clutch is required. Another characteristic is that the ICE works better at higher speeds and increasing revolutions. A common complaint was that early gasoline cars easily stalled at low speeds. ${ }^{70}$ Another problem was to transmit power from the engine to the wheels. Several options were tried, e.g. cogwheels, belts and chain-drives borrowed from bicycles. The complex gearing and transmission techniques in gasoline cars required extra space. Builders of gasoline cars began to change the chassis, in the form of an extra 'nose' (hood). Over time this 'nose' became longer, while the boxy coachwork was built lower. Gasoline cars thus developed a particular form.

In the early 1890s the main technical teething problems were solved, but the early cars were fragile and had little power. It was widely thought that the new automobile would be an urban car, because only cities had large amounts of newly created smooth asphalt and brick roads on which these fragile machines could operate. In the following years, four niches were explored by automobile pioneers. The first was the taxi, still dominated by horse-drawn hackneys and cabriolets. The gasoline car was not very suited for this niche, because of the difficulty of driving them at low speeds and frequent stops. ${ }^{71}$ Electric vehicles were easy to start and accelerate. Furthermore, because the electric tram experienced much success in these years, it seemed logical that electricity would be the way to mechanize transportation. The electric car was thought to fill in the gaps of the electric tram network. The short range of electric vehicles was not perceived as a major problem in this niche and could be dealt with through fleets of urban taxis. In the late 1890s many countries experienced a 'lead cab fever', as electric taxi's appeared on the streets of major cities: London (1897), Paris (1898) and Berlin (1899). In America electric cabs were first operated by the Electric Vehicle Company (EVC) in 1899. Between 1899 and 1902 electric vehicles enjoyed great popularity in the taxi niche. ${ }^{72}$ This enthusiasm died out however, because batteries proved to be vulnerable, suffering from frequent breakdowns. Furthermore, the EVC became embroiled in legal and financial scandals, and went bankrupt in $1903 .{ }^{73}$ So the exploration of the taxi niche by early automobiles failed.

The second niche was the luxury niche of promenading in parks, driving to picnics and tea parties. Early gasoline cars were not suited, because they were difficult to start and operate at low speeds. Hence, electric vehicles seemed an appropriate choice. The resulting electric 'society cars' were exclusive and designed to show off wealth. In a number of large American cities, automobiles were initially banned from use in parks, but automobile 
owners successfully challenged these bans in court, and in 1899 automobiles were officially being allowed into Central Park, New York. The permits were only issued for electric vehicles, because they were relatively quiet and less frightening to horses than noisy gasoline cars. ${ }^{74}$ Parks, spaces that were newly created in the Parkway movement, thus became an arena for contestation. In the luxury promenading niche, electric vehicles competed more with the traditional horse-drawn carriage than with the gasoline automobile. In this niche the short range of electric vehicles was not perceived as a problem.

The third niche was racing. The first official road race was in 1894 over $199 \mathrm{~km}$ from Paris to Rouen and back. This race attracted much interest and press publicity. The first American race was the Times-Herald race in 1895. Car races were very popular, attracting many spectators and press interest. ${ }^{75}$ The niche of car racing resonated with new cultural values at the landscape level, e.g. excitement and danger, physical prowess, elite status, masculine courage, aggressiveness and striving for records. Automobile clubs were set up to organize races: France (1895), Belgium (1896), Italy and England (1897) and the USA (1899). In short-distance races on tracks, electric vehicles gave good competition to gasoline cars, taking advantage of their momentary energy outburst, but in long-distance races electric vehicles encountered problems with the limited energy content of the lead acid battery, and low reliability and sturdiness. The racing niche played a major role in forming the perception of what 'the automobile' should be able to do. Long range and high speed were established as prominent performance criteria. These performance criteria influenced the technical form of the car, which changed from a high boxy carriage to a low and long vehicle, more aerodynamic and sportive. The new user preferences materialized in a dominant design, the Mercedes of 1901 (Figure 8).

The fourth niche was touring in the countryside. Early touring was mainly for sporting 'dare-devils', because cars were weak and often broke down, but this aspect added to the challenge and excitement of touring, allowing drivers to demonstrate their technical dexterity in making repairs. ${ }^{77}$ The touring niche was very popular because it linked up with cultural values at the landscape level, e.g. adventure and technical skill. It succeeded the bicycle as 'adventure machine'. Touring was also experienced as 'active travelling', and strengthened two new functionalities, which were first introduced with the bicycle: individual and flexible mobility. Drivers could choose their own route, not constrained by fixed rails. Touring also linked up with the health and hygiene movement at the landscape level. Driving cars in the countryside was perceived as 'practising health'. Because touring was popular, different automobiles tried to establish a foothold in this niche. There were attempts to use electric cars for touring, but these failed because of limited range, and the lack of a rural electric infrastructure for recharging. Steam car manufacturers did not really champion the use of their cars for touring. Steam car manufacturers were often

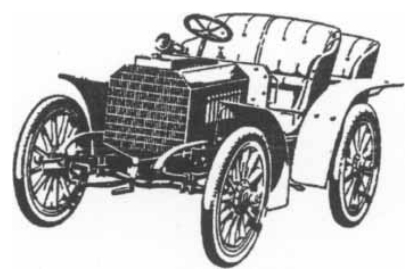

Figure 8. The Mercedes from 1901. Source: Bürgle and Frankenberg (Ref. 76, p. 15) 
master craftsmen, mainly interested in making beautiful steam cars. Because they did not care much about consumers, it remained unclear which market they targeted. ${ }^{78}$ Therefore, it was gasoline cars that conquered the touring niche. These cars could build on an existing fuel infrastructure, because petrol was widely available at general stores, e.g. for lighting purposes and stationary gasoline engines. ${ }^{79}$ Gasoline cars could also build on an existing repair network made up of farmers, smithies and mechanics with gas engine competencies. However, there was also opposition and resistance to touring, especially from the local population. Accidents happened, killing people or livestock, because drivers travelled at high speeds on bad roads. Speeding cars also caused dust waves that bothered pedestrians and wagon drivers. To oppose automobiles, farmers sometimes ploughed roads to make them unsuitable. The Farmers Institute of Indiana asked for a ban on cars from using rural roads. ${ }^{80}$ Influential periodicals such as The American Agriculturalist and Farm Journal expressed concerns about speeding. The opposition from farming communities and anti-speed organizations jeopardized the standing of the automobile. In reaction, automobile clubs lobbied for favourable legislation and defended drivers against criminal suits. Public authorities began a regulatory process to embed the car institutionally, thus defusing opposition. ${ }^{81}$ Car registration and car tags were introduced to facilitate identification of cars and drivers in case of accidents. An institutional response to reckless driving was the licensing of drivers. Speed limits were introduced, but these were rather favourable. Local speed limits were raised from 6 to $12 \mathrm{mph}$ within city limits in 1901 and to 20 mph outside the city limits in $1905 .{ }^{82}$ Traffic rules were devised to create more order on the street. In 1903 the New York Police Commissioner issued traffic rules to separate different traffic modes to facilitate the flow (slow vehicles on the side of the street, fast vehicles in the middle). In sum, by 1903 a stable distribution of functions emerged with regard to automobiles. Electric vehicles were defined as urban cars, used in the taxi niche and the promenading niche. In the taxi niche, however, the early success of electric vehicles was not sustained as the Electric Vehicle Company went bankrupt in 1903. Gasoline cars were defined as 'adventure cars', used in the racing and touring niches. Because these different niches were relatively separate, electric and gasoline cars did not compete directly.

In terms of the multi-level perspective this second period saw many multi-level interactions. The horse-based regime experienced growing problems on technical and economic dimensions, and also linked up negatively with the increasing cultural concerns at the landscape level with health and hygiene. These regime problems created a window of opportunity for the breakthrough of the electric tram, which rapidly developed from the technological niche in the early 1880 s, the market niche in 1888 , to a new regime by the mid-1890s. On the one hand this rapid development was stimulated by nicheinternal drivers such as price/performance improvements and the support of powerful social groups (e.g. horse tram companies, electric utilities, real estate agents, local authorities and urban reformers), while on the other hand, the electric tram linked up positively with an external landscape development, the cultural enthusiasm about electricity. Multilevel linkages also occurred with regard to two other niche innovations, the bicycle and automobile. Bicycles and automobiles linked up positively with the health and hygiene movement at the landscape level, because they were both seen as positive ways to experience nature and inhale fresh air. The mobility practice of touring was popular, because it linked up with cultural landscape values such as recreation, fun and entertainment. The mobility practice of racing was also popular, because it linked up with landscape values 
such as excitement and danger, appreciation of speed, and striving for records. This period also showed the importance of niches in the emergence of new technologies, illustrated in particular for different automobiles that became linked to different market niches (taxi, luxury promenading, racing and touring). The heating up of the horse-based regime and the emergence of new transport options led to more fluidity and diversity in urban transportation. Some of the new transport options (in particular the electric tram and bicycle) had wider socio-technical knock-on effects, e.g. change in the perception of the function of the street (from social meeting place to transport artery), changing attitude towards highspeed vehicles in streets, change in user preferences and mobility practices (individual, flexibile, fast and fun), lobby for smoother road pavements and change in the administration of streets. Because all these new elements created a favourable context for the later breakthrough of automobiles, the 1890s formed a crucial period in the overall transition.

\section{Expansion of Electric Trams and Stabilization of a Technical Car Regime (1903-1914)}

This period saw the continuation of landscape developments from the previous period. Immigration increased to about 1 million immigrants per year, exacerbating the urban problems of overcrowding, pollution and health problems. ${ }^{83}$ These problems received much attention in the ongoing Progressive Reform movement. Reformers embraced sub-urbanization as a way to deal with urban problems.

In this period, horses were increasingly replaced by passenger transport. While they were already replaced in tram transport, they also came under fire in taxi transport, especially once gasoline taxis appeared in 1907. In the luxury niche horse-drawn carriages had already faced some competition from electric vehicles in the previous period. As automobiles were technically improved, they also began to replace horse-drawn carriages in practical niches. For instance, doctors started to buy automobiles to visit their patients, initially often as an additional option. Other professional groups followed, e.g. rich farmers (to bring produce to market), salesmen and insurance agents to visit their clients. So gradually, the horse disappeared in urban passenger transport, but horses held on in the market niche of freight transport. In this market niche there was a prolonged competition between horse-drawn wagons, electric trucks and gasoline trucks. ${ }^{84}$ Freight transportation thus provided a niche where horse-drawn transport could persist until World War II. In this way social groups related to horse-transport were not immediately threatened with unemployment, reducing social unrest (e.g. smiths, wheelwrights, cart, van and wagon makers, fitters, painters, coachmen, carriers, horse keepers and stable keepers).

In this period, the electric tram enjoyed great expansion. By 1900 there were around 850 trolley systems in American cities operating over 10,000 miles of track. Figure 9 gives an impression of the rise in yearly passengers. The trolley was widely used by middle classes for commuting between work in the city and suburban houses. The strongest growth occurred in the interurban tram systems between communities. The electric interurban mileage increased from 2107 miles in 1900 to a peak of 15,580 miles in $1916{ }^{85}$

Despite its expansion, the electric tram regime experienced problems on different dimensions. First, the trolley was strongly regulated with regard to fares and transfers. Local policy makers prevented tram companies from increasing prices, which long remained at five cents. ${ }^{87}$ They also instated universal transfer, paying per ride rather than distance. These regulations made it difficult for trolley companies to increase 


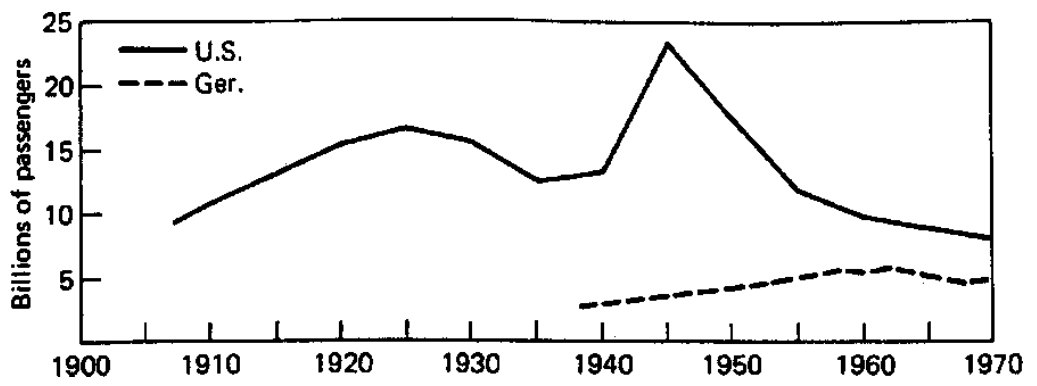

Figure 9. Yearly passengers in the electric tram in the US and Germany. Source: Yago (Ref. 86, p. 9)

income. ${ }^{88}$ Second, trolley companies acquired a negative public image. In the 1890 s and the early 20th century they had made large profits through real-estate speculation. Publication of some speculative excesses gave them the public image of greedy and rich monopolists. ${ }^{89} \mathrm{~A}$ third problem was a decline in the standard of comfort, in particular overcrowding at rush hours. Overcrowding resulted in delayed services, breakdowns and dirty carriages. Another reason for complaint was the inflexibility of routing. As factories were set up on the outskirts of cities, workers often first had to travel to the city centre and then take another tram to the factory. The failings of mass transit were seen as a broken promise. Trolley companies seemed to be more interested in money than in 'proper' transportation.

Although the bicycle had been a popular new technology in the 1890s, it lost its prominence in the early 20th century. In the late 1890s labourers used bicycles for practical work, e.g. as delivery tricycles for freight transport. ${ }^{90}$ In the 1910 s, however, the use of bicycles in America declined and they were increasingly considered as children's toys. ${ }^{91}$

In 1900, automobiles were still toys for the upper classes, playing a minor role in terms of overall mobility. Gasoline cars were used by rich sportsmen and adventurous tour drivers, while electric vehicles served as luxury cars in cities (e.g. promenading and tea parties). From 1903 to 1907 this relative separation persisted. Steam-driven and electric vehicles kept up their numbers in their market niches (see Table 1), but the number of gasoline automobiles raced ahead, because it linked to popular application domains. Touring in the countryside especially witnessed a great expansion between 1902 and $1907 .{ }^{92}$

After 1905, new groups began to use cars for business purposes, e.g. doctors, travelling salesmen and insurance agents. While farming communities had initially opposed automobiles, wealthy farmers gradually switched camps and began to use cars as a practical vehicle for transportation of goods and people. Another commercial niche was that of the taxi. Gasoline taxi's appeared in 1907, replacing horse-drawn hackney carriages.

Table 1. Annual car sales in the USA

\begin{tabular}{lrr}
\hline & 1900 & 1905 \\
\hline Electric cars & 1575 & 1425 \\
Steamers & 1681 & 1568 \\
Gasoline cars & 936 & 18,699 \\
Total & 4192 & 21,692 \\
\hline
\end{tabular}

Source: Based on data from Kirsch (Ref. 72), and Mom (Ref. 42). 
The taxi-niche was the trailblazer of a more utilitarian use of gasoline cars. Automobile touring remained important, but gradually changed its character, as it developed into auto camping after 1910 , a vacation alternative for the middle class. ${ }^{93}$ In the early 20th century, automobiles were still large and luxurious. Olds and Ford pioneered a new trajectory of cheap, strong, sturdy cars. Ford wanted to build cheap cars, without sacrificing strength. After years of experimenting he found the 'right' balance between cheap price and sufficient robustness in his Model T priced at US\$850 in 1908. Its basic merit lay in the combination of lightness, sturdiness, simplicity and power. The new technical trajectory was more widely embraced in the car industry, after sales dropped in 1907, signalling saturation of the luxury market. This stimulated manufacturers to find new markets and they turned to Ford's idea to go down-market. The Model T created a dominant design for the car industry, allowing engineers to focus on incremental product innovations and improvements in production technologies to bring down prices. One important product innovation was the electric starter, developed in 1911. Starting had been a complicated matter for internal combustion engines, because a crank had to be turned around rapidly and with great force. Using high voltage ignition on the basis of batteries, the electric starter solved the problem of starting gasoline cars. Because gasoline cars became easier to start, electric vehicles lost an important relative advantage. There was much societal enthusiasm about the diffusion of automobiles. They became status symbols and also represented power, success and audacity. Attention was also drawn towards more practical usages of automobiles and the shift from large luxury models to simple, cheap and sturdy cars. Progressive reformers particularly welcomed these developments, because they increasingly saw automobiles as a tool to facilitate suburban living. ${ }^{94}$

The electric vehicle did not stabilize in a dominant design and hence scale economies and lower cost were not achieved. By 1905 a second generation of electric cars characterized by more reliable and stronger batteries was displayed at car shows. Between 1907 and 1910 there was a brief resurgence of interests - the 'golden age' of electric vehicles. ${ }^{95}$ However, the electric car was increasingly confined to small market niches, a 'societyvehicle' for tea parties and promenading. After 1911 gasoline cars with electric starters invaded even this last niche of electric vehicles. Although electric and steam cars remained viable for several years after 1910, it was clear that the electric vehicle had lost the battle with the gasoline car.

In terms of the multi-level perspective there was some interaction in this third period between landscape changes and niche dynamics, in particular between urban problems, sub-urbanization as a way of social reform, and the automobile as a means to that end, but the main dynamics in this period were changes in the relative importance of different transport options. Horses disappeared from urban passenger transport. The bicycle lost importance, and became a children's toy. The electric tram further expanded and became the dominant urban transport system. Gasoline automobiles stabilized and captured more market niches. This set the stage for the fourth period, in which electric trams and gasoline automobiles increasingly competed.

\section{Towards a Car-based Personal Transportation Regime and its Impact (1914-1930s)}

Important landscape developments were ongoing transformations in urban and rural areas. An ongoing transformation of the city was sub-urbanization. A cultural desire for suburbia had existed for decades, as a reaction to social problems in the city. The diffusion of the 
electric tram had enabled the middle classes to leave the city centre and set up house in the suburbs. A complementary development was the creation of central business districts in many large American cities. Cultural activities such as theatres, museums and cinemas were also situated in the city centre, as was shopping in department stores. ${ }^{96}$ The diffusion of automobiles would link up to these urban transformations and reinforce them. Rural society also experienced major changes. One development was a growing opposition and aversion against train companies, which, for decades, had enjoyed a monopoly on the long-distance transport of produce. Railroad policy was to charge farmers high rates, sometimes demanding more to ship crops over short distances than over long hauls. Hence, the railroad industry became the focus of rural protest. An important reason that the automobile became popular in the 1910s was that it allowed farmers to circumvent trains and bring produce to markets themselves. A second rural development was the decline of rural organizations. As more people moved to live in cities, many rural schools, churches, shops and medical facilities were eroded and eventually shut down. Isolation of farm people and the weakening of rural organizations were important topics in social and political discussions. The car became popular with farmers because it could bring them to church, to larger shops, and transport their children to school. The automobile fulfilled a demand for a social alternative to the dysfunctional communal life of the open countryside by 1910. ${ }^{97}$ Policy makers stimulated the car and legitimized road building in rural areas as a means to overcome social isolation of farm communities.

These urban and rural landscape developments helped to make automobiles a serious competitor for the electric tram. In the 1920s and 1930s the electric tram regime also faced internal problems and tensions. One problem was financial. Wage and material costs increased, especially during World War I. Because fares were strongly regulated, tram companies had few ways to increase income. Only in the late 1920 s were fares allowed to go up to seven cents. So, tram companies built up financial debts and had no funds for expansion and improvement of the lines. The public had little sympathy with trolley companies, because of their negative public image and the large profits they had made in earlier years. The second problem was political. Policy makers saw tram companies as handy villains that had previously used their concessions to make huge profits. Hence, public authorities were not inclined to help financially. In fact, they embraced the car and motorbus, and fought with trolley companies. While the trolley was taxed, the private automobile and motorbus were massively subsidized by publicly funded street improvements. ${ }^{98}$ A third problem was that user satisfaction with the trolley declined after the mid-1910s. Trams became more crowded, especially during rush hour. Another complaint, especially from women, was sexual harassment. The overcrowding in trams created ample opportunities for 'accidental' contact and blatant fondling. The feelings of insecurity were mixed with racism, as more Afro-American workers used trolleys to get to work. ${ }^{99}$ Another effect of low investments was more breakdowns and decreasing punctuality of service. Furthermore, the experience of speed changed as automobiles became more widespread. Because automobiles moved $40-45 \%$ faster than trams, the latter were increasingly thought of as slow. ${ }^{100}$ In sum, the de-alignment of the trolley regime was the result of a range of political, social and economic causes. By the late 1910s track mileage began to shrink, followed by declining passenger numbers after $1924 .^{101}$ The real decline in passengers took place in the 1930s (see Figure 9). During World War II there was a brief rise in passenger numbers, followed by a consistent decline in the post-war period. 
Between 1914 and 1930 the automobile was sold in ever-larger numbers. On the one hand, internal drivers stimulated their diffusion, for instance major price reductions that were enabled by mass production. Ford experimented and pioneered the assembly line in the 1910s, consisting of conveyor lines, specialized machine tools organized in a sequential manner, sub-division of labour and interchangeability of parts. ${ }^{102}$ The Model $\mathrm{T}$ was offered for increasingly cheaper prices (from US\$850 in 1908 to $\$ 360$ in 1916), which stimulated diffusion. Another internal driver was the support by powerful social groups, e.g. the road lobby, highway engineers and policy makers, who saw cars as a means to stimulate suburbanization. On the other hand, the diffusion of automobiles was stimulated because of linkages with external landscape developments in urban and rural areas. Farmers were a major market niche in the 1910s, because cars provided an answer to problems in rural areas related to landscape developments (circumvent train companies, isolation, decline of rural organizations). Urban middle classes also formed a major market niche in the 1910s, using cars to commute between work and home. Cars linked up with the landscape development of suburbanization and reinforced it. In the 1920s cars were bought by new middle class customer groups that were less mechanically sophisticated and less tolerant of inconvenient operation. As ease of operation, smoothness of ride, comfort and convenience became important performance criteria, cars developed into 'rolling living rooms'.

The diffusion of cars was accompanied and made possible by the creation of a new socio-technical regime that was tailored to its demands. New regulations were one element of this regime, often reformulated in favourable ways. Speed limits from previous years were relaxed, regulations were adopted to organize traffic flow around the car and educational efforts were undertaken to control pedestrian behaviour. ${ }^{103}$ The guiding principle in 19th-century traffic regulations was the safety of street users. In the early 20th century, rapid and efficient traffic flow became more important than pedestrian safety. To increase traffic flow and prevent congestion new regulations were issued, e.g. banning left-hand turns and introducing 60 min parking limit. As the speed and number of automobiles increased, so did the number of accidents. Around $75 \%$ of the car's victims were pedestrians, mostly children playing in the street. ${ }^{104}$ To remove children from the street, more playgrounds were built to give children alternative spaces. Another response was to teach pedestrians new routines. Educational campaigns in the 1910 s (e.g. at public schools) taught that pedestrians could cross safely only if they remained alert and followed special procedures. Also drivers were required to learn new routines to reduce accidents, signalled by an expansion of driving schools. The task was not to teach general driving skills, but to discipline drivers not to speed, not to get agitated and respect general traffic rules. Before World War I a 'morality of good traffic manners' was articulated. ${ }^{105}$ As a result of these regulatory changes, streets were the exclusive property of automobiles by 1920, confining pedestrians to the sidewalks. Another element of the new socio-technical regime was the improvement of road infrastructures. This involved the paving and widening of existing roads and the building of new roads. Road improvements required major investments, paid by public authorities. In 1906, for instance, US\$300 million was spent on urban roads. ${ }^{106}$ City engineers and urban planners created a new suburban territory around cars and reshaped urban downtowns by repaving, street widening and bridge construction. ${ }^{107}$ The reforms also resulted in a new kind of road, highways, only to be used by motor vehicles. The first highways were built in and around cities, e.g. on Long Island in 1914 and the Bronx in 1923. As 
downtown congestion increased, plans to build highways became more widespread in the 1920s. Urban policy makers invested massively in roads, but only limitedly in public mass transit. ${ }^{108}$ While urban roads were being improved, rural roads were still in a bad state. In the 1910s several social groups joined the Good Roads movement to lobby for improved rural roads. One group were farmers who saw rural roads as a way to circumvent the railway companies. Another group were motorists themselves, who formed the American Automobiles Association. A third group were road builders and cement manufacturers, who had major markets to win. In response to this pressure, new departments were created and staffed with highway engineers. Highway engineers professionalized themselves by creating specialized highway departments and professional associations, e.g. the American Association for Highway Improvement, founded in 1911. ${ }^{109}$ In 1916 president Wilson signed the first Federal Aid Road Act into law, creating the new federal Bureau of Public Roads (BPR) to oversee rural road construction. In the following years, the BPR's budget was substantially increased. As the 1920s progressed, the BPR developed into a well functioning 'highway machine', involving a large network of interrelated groups, that formed a strong highway lobby, e.g. the Portland Cement Association, the American Automobile Association, the American Road Builders Association, the Association of Highway Officials, the Rubber Association of America, the Mississippi Valley Association of State Highway Officials, the National Paving Brick Manufacturer's Association and the National Automobile Chamber of Commerce. ${ }^{110}$ In response to the Great Depression, federal highway aid was further increased. Between 1933 and 1944, the New Deal resulted in more than US $\$ 1.8$ billion for new roads, thus funding the highway boom of the 1930s. ${ }^{111}$

As the car diffused it had wider impacts on society. It facilitated the emergence of a 'car culture', supported by new institutions such as fast food restaurants on highways, shopping malls on the edge of cities, drive-in movies. Touring with automobiles developed into a popular recreation activity. The car developed many forward and backward linkages in the economy of the 1930s. The automobile industry was a huge consumer of sheet steel, glass and paint, components (tyres, lamps, generators, etc.), and machine tools. The use of the car boosted the petroleum industry and construction and public works (roads, bridges and tunnels). In sum, the car became strongly embedded in society. Although not everybody owned a car in the 1930s, the automobile was clearly the way forward.

In terms of the multi-level perspective the main interaction in the fourth period was that transformations in urban and rural areas at the landscape level created a 'latent demand' for cars by suburbanites and farmers. Linking up with this latent demand, the car could diffuse rapidly in the 1910s and 1920s, as it captured these big market niches. The main dynamic was the competition between two regimes. The electric tram regime lost this competition, because of tensions on political, social and economic dimensions. The automobile regime gained increasing momentum, because of internal drivers (price/ performance improvements and support from powerful social groups) and positive linkages with landscape developments.

\section{Conclusions and Conceptual Refinements}

To answer the research question the second section described a conceptual multi-level perspective that distinguished three levels: technological niche, socio-technical regime 
and socio-technical landscape. The main point of the perspective was that transitions come about through the alignment and interaction of dynamics at all three levels. It was also argued that the dynamics are not mechanical and linear, but come about through the interactions of social groups with different interests, strategies and values. The third section described a historical case study to illustrate this perspective. The conclusions at the end of the sub-sections in the case description made the multi-level interactions explicit. Especially in the second period there were many such interactions, as major landscape changes in the society at large created high pressure on the regime and windows of opportunity for niches. However, the other periods were also characterized by important multilevel interactions. So it can concluded that the case study replicated the basic point about multi-level interactions in transitions. The case study also demonstrated the usefulness of the niche-concept to understand both the emergence and diffusion of radical innovations. It was shown in detail how steam, electric and gasoline automobiles emerged as technical novelties in the 1880s, and then became linked to different niches. Electric vehicles became linked to the taxi niche (but failed in 1903) and the urban luxury niche, for tea parties and promenading in parks. Gasoline cars were used in the racing and touring niche. For steam automobile manufacturers it remained unclear which market they targeted. The niche analysis was also useful to understand the further diffusion of automobiles as a trajectory of niche accumulation (see Figure 10).

The case study also demonstrated that the dynamics of transitions are carried by the interactions of social groups. Several antagonistic struggles and strategic coalitions were described, for instance: (a) the coalition of groups to stimulated the rise of the electric tram in the 1890s (horse tram companies, electric utilities, real estate agents, local authorities and urban reformers); (b) the struggle in the 1890s between local residents and local authorities about road pavements; (c) the resistance in the early 1900s of farmers against speeding automobilists; (d) the coalition of groups that formed the highway lobby in the 1930s to stimulate cars and road building (automobile user clubs, highway engineers, cement, road and construction companies, chambers of commerce). Such struggles and antagonistic interactions give transitions a non-linear and contested character. Whether or not transitions take place depends partly on strategic manoeuvring, the building of coalitions and power, and partly on wider developments at regime and landscape level that create or close windows of opportunity.

The case study not only demonstrated the main points from the multi-level perspective, but also showed that the transition from horse-drawn carriages to automobiles was more complex than represented by the technological substitution approach. The case study also shows that Nelson's representation was too simple when he claimed that 'If the roll of the dice early in the history of automobiles had come out another way, we might today have had steam or electric cars'. The case study showed that the linkages of different types of automobile to different niches was not a complete coincidence, but depended on technical, infrastructural and cultural elements. In particular, the gasoline car conquered the touring niche and long-distance racing niche, because of technical characteristics of the internal combustion engine and because it could build on an existing petrol infrastructure, and an existing maintenance network and repair skills (crucial aspects that were hindering the use of electric vehicles outside cities). The basic problem with economic path dependence arguments is the assumption that there is one homogeneous selection environment in which different technologies (e.g. automobiles) compete. This was incorrect for the early automobiles, which did not compete directly, because they were used in relatively 


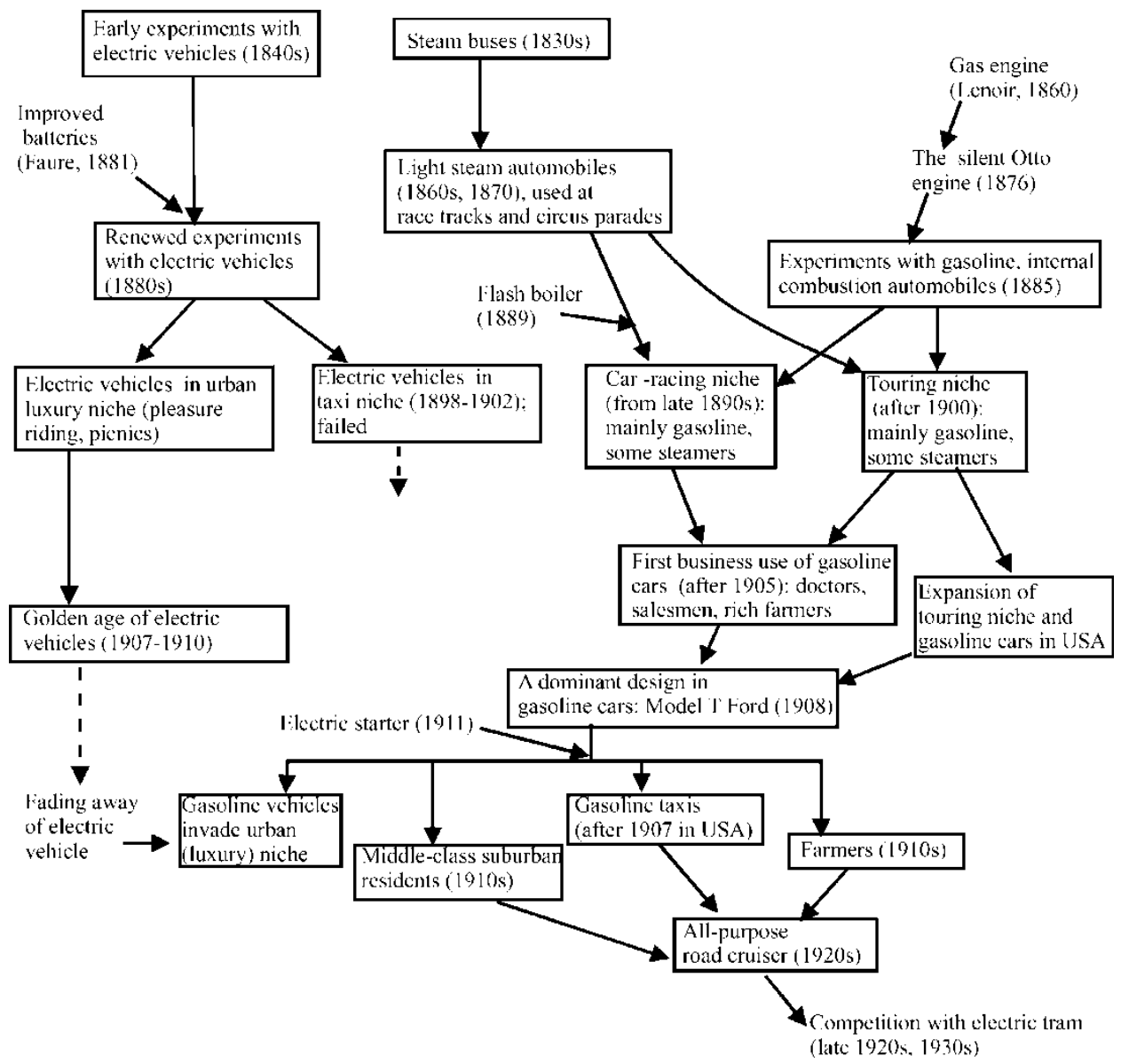

Figure 10. Trajectory of niche accumulation for the emergence and diffusion of automobiles

separate niches. The reason that gasoline cars gained a lead in the first years of the 20th century was the growth of the touring niche, not increasing returns to adoption.

The case study also had some deviations from the multi-level perspective as it was described in second section. The first deviation was that the incumbent regime suffered tensions in the early phases of the transition, while the multi-level perspective maintained that the regime would be stable. In the MLP description pressures from landscape developments and tensions in the regime did not occur until the third phase. In the case study major landscape changes and regime tensions already occurred in the first and especially in the second phase. While this may seem a minor difference, it has important implications for niche dynamics. In the MLP description niche innovations have difficulty in the early phases in attracting attention and funding, because the existing regime is stable. Things work out differently if the regime becomes unstable in the early phase. When actors lose faith in the regime, they may engage in search activities or sponsor emerging innovations. So, while a stable regime is likely to block niche innovations, a regime that becomes unstable may draw niche innovations out of the dark and give them wide 
exposure. In the case study this happened in particular with electric trams, but also with automobiles and bicycles. The second deviation in the case study is that many new transport innovations emerged in niches in the first and second period, while the MLP description conceptualized only one innovation. On the one hand, the emergence of many innovations in the case study depended on the presence of technological opportunities, in particular steam engines, internal combustion engines and improved electric motors that could be added to existing trams, carriages and tricycles. On the other hand, these novelties needed money and attention for their further development. That provides a link with the first deviation, because money and attention were available, because problems in the urban horse-based transport regime made important actors, such as horse tram companies, willing to sponsor innovations, such as the electric tram. Niche innovations also received much attention and funding, because they linked up positively with new cultural landscape values. Bicycles and automobiles linked up with values related to entertainment, sport, excitement, experiencing of nature and 'practicing health', while the electric tram and electric cars linked up with the widespread enthusiasm about electricity. The presence of many transport innovations forms the basis for a third deviation. While the MLP description looks like a technological substitution process with added social, cultural and infrastructural complexities, the case study followed a different overall pattern, consisting of widening up and narrowing down. The tensions in the horse-based regime created space for experimentation with multiple innovations, leading to an initial widening of the number of transport technologies. Between 1880 and 1910 many options co-existed, although the electric tram became dominant in terms of total mobility. In the 1920s and 1930s the electric tram regime declined, because of internal problems and increased competition from the automobile regime, which eventually became dominant. The overall pattern of opening up and narrowing down means that the automobile was the last step in a wider and longer transformation process (Figure 11).

The presence of multiple innovations also gave rise to interesting dynamics in the case study. The different transport innovations not only competed with each other, but also had positive interactions, both in a parallel and sequential manner. Parallel interactions refer to positive feedbacks between co-existing technologies. For instance, the electric vehicle 'borrowed' the mechanical controller from the electric tram, a device that allowed easy gearing, and the gasoline car 'borrowed' batteries and high voltage ignition from the electric vehicle, resulting in the electric starter. Sequential interactions refer to relationships between technologies that follow upon each other over time, in particular when one technology builds upon changes that were triggered by a previous technology. The case study showed that the use and societal embedding of bicycles and electric trams had many sociotechnical knock-on effects that created a positive context for the later diffusion of the automobile. The bicycle and electric tram helped to create many new elements that paved the way for the automobile, for example new mobility practices and user preferences, changing perception of the function of streets, becoming used to vehicles with higher speed, the Good Roads movement for smoother pavements, more power for public authorities in the administration of streets, development of new technical elements. Because of these socio-technical knock-on effects, the bicycle and electric tram acted as catalysts in the transition towards automobiles. ${ }^{112}$ The success of the automobile was enabled by the previous transformations.

As indicated above, there are logical connections between the three deviations. Therefore it is proposed to distinguish a specific transition pathway within the multi-level 


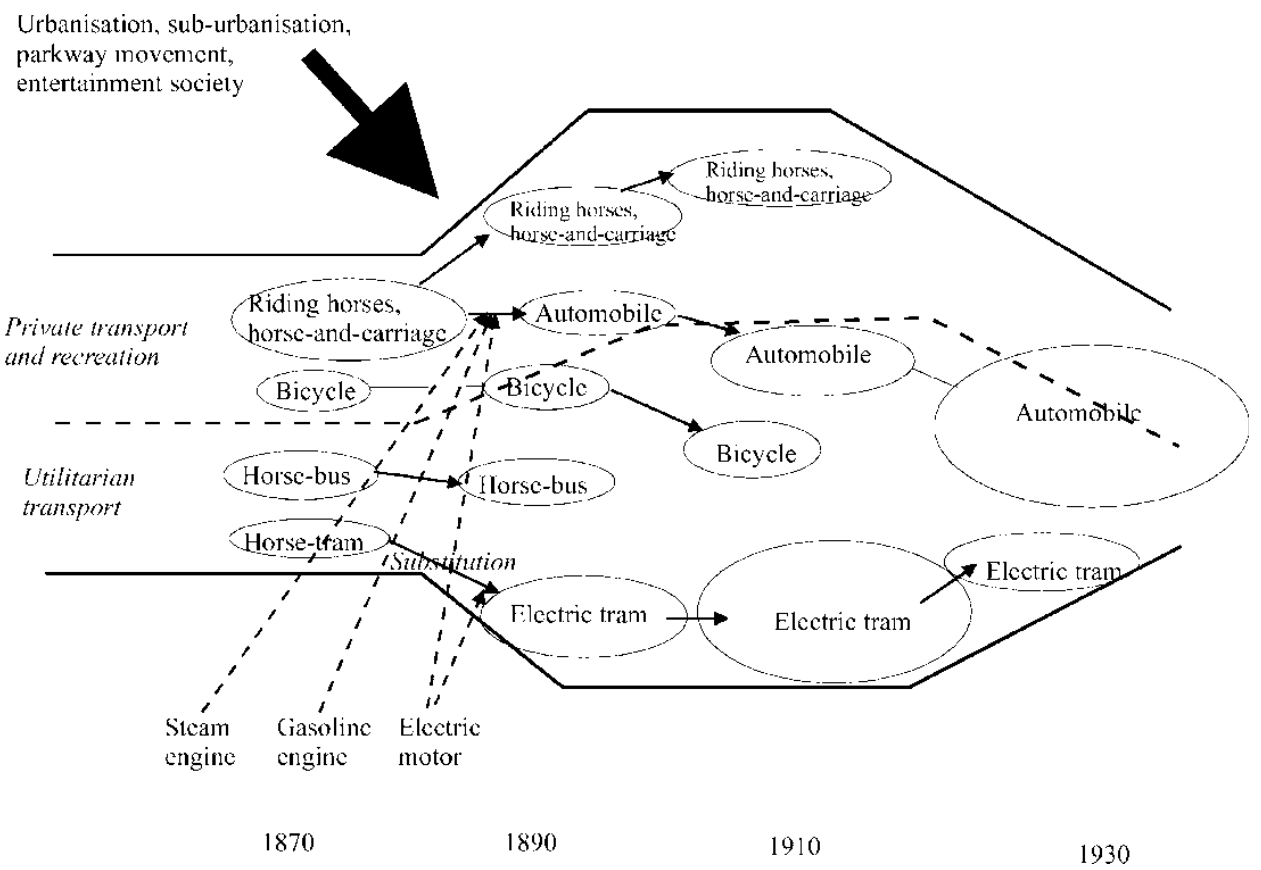

Figure 11. Widening up and narrowing down

perspective, called 'de-alignment and re-alignment'. This pathway has the following characteristics. First, the elements in the socio-technical regime de-align early in the process, because of internal tensions and pressure from the landscape level. Second, the instability of the regime creates space for the emergence and development of multiple innovations in different niches. When these innovations promise solutions to the regime

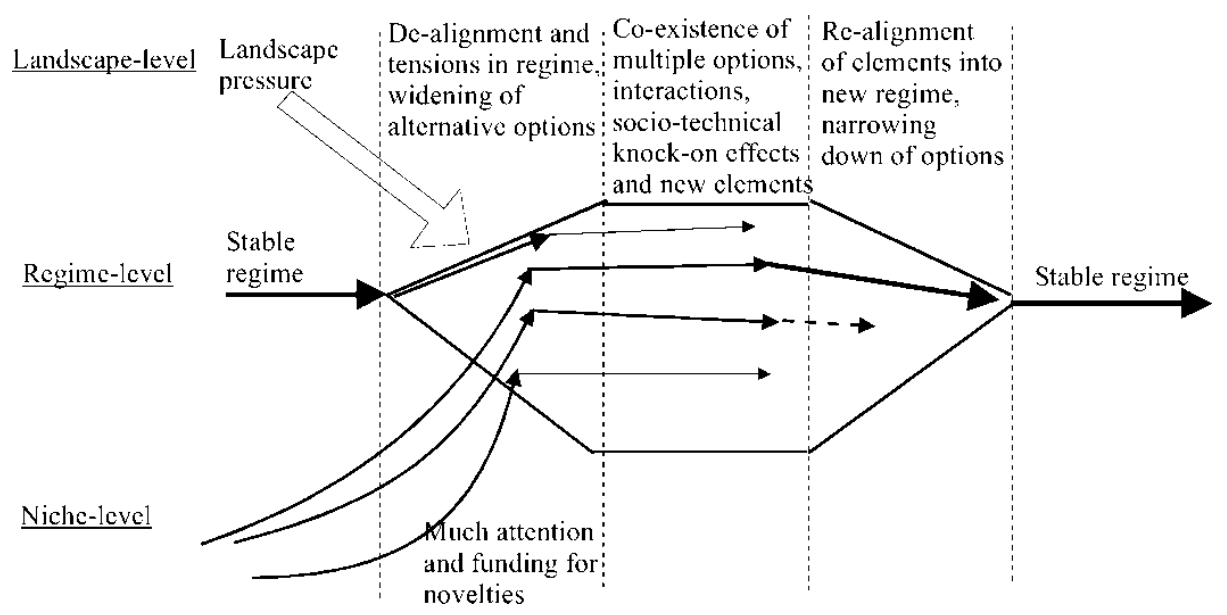

Figure 12. De-alignment and re-alignment transition pathway 
problems or link up positively with wider landscape changes, they will easily receive attention and funding. Third, the transition involves a pattern of widening up and narrowing down of the number of innovations. Opening up occurs early in the process, followed by a co-existence of different innovations for a long time. These innovations may have parallel and sequential interactions, and lead to socio-technical knock-on effects in markets, user preferences and practices, cultural meaning and infrastructure. Eventually the number of alternative options narrows down and one option becomes dominant. Socio-technical elements are re-aligned around this option, leading to a new socio-technical regime (see Figure 12). This conceptual refinement indicates that distinctive transition pathways can be developed within the multi-level perspective. One such pathway has been elaborated in this article. Maybe more can be found in the future, using contrasting case studies as inspiration for theory development.

\section{Acknowledgements}

I want to thank Geert Verbong, Rob Raven and two anonymous referees for their useful comments on previous versions of this paper. I also gratefully acknowledge financial support from the Dutch Knowledge Network on System Innovation (KSI).

\section{Notes and References}

1. T. P. Hughes, The evolution of large technological systems, in: W. E. Bijker, T. P. Hughes \& T. Pinch (Eds) The Social Construction of Technological Systems: New Directions in the Sociology and History of Technology (Cambridge, MA, The MIT Press, 1987), pp. 51-82.

2. F. W. Geels, From sectoral systems of innovation to socio-technical systems: insights about dynamics and change from sociology and institutional theory, Research Policy, 33(6-7), 2004, pp. 897-920.

3. Hughes, op. cit., Ref. 1; T. P. Hughes, Networks of Power: Electrification in Western Society, 18801930 (Baltimore, MD, Johns Hopkins University Press, 1983); R. Mayntz \& T. P. Hughes (Eds), The Development of Large Technical Systems (Boulder, CO, Westview Press, 1988).

4. F. Malerba, Sectoral systems of innovation, Research Policy, 31(2), 2002, pp. 247-264 (p. 259).

5. P. A. David, Clio and the economics of QWERTY, American Economic Review, 75, 1985, pp. 332-337.

6. W. B. Arthur, Competing technologies: an overview, in: G. Dosi, C. Freeman, R. Nelson, G. Silverberg, \& L. Soete (Eds) Technical Change and Economic Theory (London, Pinter, 1988), pp. 590-607.

7. Ibid.

8. R. R. Nelson, Recent evolutionary theorizing about economic change, Journal of Economic Literature, 33, 1995, pp. 48-90 (pp. 74-75).

9. W. Walker, Entrapment in large technology systems: Institutional commitments and power relations, Research Policy, 29, 2000, pp. 833-846.

10. R. R. Nelson \& S. G. Winter, An Evolutionary Theory of Economic Change (Cambridge, MA, Bellknap Press, 1982); G. Dosi, Technological paradigms and technological trajectories: a suggested interpretation of the determinants and directions of technical change, Research Policy, 6, 1982, pp. 147-162.

11. D. Leonard-Barton, Core capabilities and core rigidities: a paradox in managing new product development, Strategic Management Journal, 13, 1992, pp. 111-125.

12. M. Tushman \& P. Anderson, Technological discontinuities and organization environments, Administrative Science Quarterly, 31, 1986, pp. 493-465.

13. T. P. Hughes, Technological momentum, in: M. R. Smith \& L. Marx (Eds) Does Technology Drive History? The Dilemma of Technological Determinism (Cambridge, MA, The MIT Press, 1994), pp. $101-113$.

14. G. C. Unruh, Understanding carbon lock-in, Energy Policy, 28, 2000, pp. 817-830.

15. M. Callon, Techno-economic networks and irreversibility, in: J. Law (Ed.) A Sociology of Monsters, Essays on Power, Technology and Domination (London, Routledge, 1991), pp. 132-161.

16. A. Grübler, Technology and Global Change (Cambridge, Cambridge University Press, 1998). 
17. N. Nakićenović, The automobile road to technological change: diffusion of the automobile as a process of technological substitution, Technological Forecasting and Social Change, 29, 1986, pp. 309-340.

18. Grübler, op. cit., Ref 16; p. 64.

19. Nakićenović, op. cit., Ref 17; p. 316.

20. R. Kemp, Technology and the transition to environmental sustainability. The problem of technological regime shifts, Futures, 26(10), 1994, pp. 1023-1046; J. Schot, R. Hoogma \& B. Elzen, Strategies for shifting technological systems. The case of the automobile system, Futures, 26, 1994, pp. 1060-1076; A. Rip \& R. Kemp, Technological change, in: S. Rayner \& E. L. Malone (Eds) Human Choice and Climate Change, Vol. 2 (Columbus, OH, Battelle Press, 1998), pp. 327-399; R. Kemp, J. Schot \& R. Hoogma, Regime shifts to sustainability through processes of niche formation: the approach of strategic niche management, Technology Analysis \& Strategic Management, 10, 1998, pp. 175-196; F. W. Geels, Technological transitions as evolutionary reconfiguration processes: a multi-level perspective and a case-study, Research Policy, 31(8/9), 2002, pp. 1257-1274; F. W. Geels, Technological Transitions and System Innovations: A Co-evolutionary and Socio-Technical Analysis (Cheltenham, Edward Elgar, 2005); B. Elzen, F. W. Geels \& K. Green (Eds), System Innovation and the Transition to Sustainability: Theory, Evidence and Policy (Cheltenham, Edward Elgar, 2004).

21. Nelson \& Winter, op. cit., Ref. 10.

22. Rip \& Kemp, op. cit., Ref. 20.

23. Geels, op. cit., Ref. 2.

24. Hughes, op. cit., Ref. 1.

25. Unruh, op. cit., Ref. 14

26. Walker, op. cit., Ref. 9.

27. J. W. Schot, The usefulness of evolutionary models for explaining innovation. The case of the Netherlands in the nineteenth century, History of Technology, 14, 1998, pp. 173-200.

28. H. S. Brown, P. Vergragt, K. Green \& L. Berchicci, Learning for sustainability transition through bounded socio-technical experiments in personal mobility, Technology Analysis \& Strategic Management, 15(3), 2003, pp. 291-315.

29. P. P. Saviotti, Technological Evolution, Variety and the Economy (Cheltenham, UK, Edward Elgar, 1996); D. A. Levinthal, The slow pace of rapid technological change: gradualism and punctuation in technological change, Industrial and Corporate Change, 7(2), 1998, pp. 217-247; K. Frenken, P. P. Saviotti \& M. Trommetter, Variety and niche creation in aircraft, helicopters, motorcycles and minicomputers, Research Policy, 28, 1999, pp. 469-488.

30. Schot et al., op. cit., Ref. 20; Kemp et al., op. cit., Ref. 20; R. Kemp, A. Rip \& J. Schot, Constructing transition paths through the management of niches, in: R. Garud \& P. Karnoe (Eds), Path Dependence and Creation (Mahwah, NJ, Lawrence Erlbaum, 2001), pp. 269-299; R. Hoogma, R. Kemp, J. Schot \& B. Truffer, Experimenting for Sustainable Transport: The Approach of Strategic Niche Management (London, Spon Press, 2002).

31. Rip \& Kemp, op. cit., Ref. 20.

32. Geels, op. cit., Ref. 20.

33. Similar, but slightly different, the descriptions of the four phases are given by Rotmans et al. (2001) and Perez (2002). See J. Rotmans, R. Kemp \& M. van Asselt, More evolution than revolution: transition management in public policy, Foresight, 3(1), 2001, pp. 15-31; C. Perez, Technological Revolutions and Financial Capital: The Dynamics of Bubbles and Golden Ages (Cheltenham, Edward Elgar, 2002).

34. C. Freeman \& C. Perez, Structural crisis of adjustment, business cycles and investment behaviour, in: G. Dosi, C. Freeman, R. Nelson, G. Silverberg \& L. Soete (Eds) Technical Change and Economic Theory (London, Pinter, 1988), pp. 38-66.

35. Geels, op. cit., Ref. 20.

36. F-M. Belz, A transition towards sustainability in the Swiss agri-food chain (1970-2000): using and improving the multi-level perspective, in: B. Elzen, F.W. Geels \& K. Green (Eds) System Innovation and the Transition to Sustainability: Theory, Evidence and Policy (Cheltenham, Edward Elgar, 2004), pp. 97-113.

37. R. P. J. M. Raven, Implementation of manure digestion and co-combustion in the Dutch electricity regime: a multi-level analysis of market implementation in the Netherlands, Energy Policy, 32, 2004, pp. 29-39.

38. H. Van Driel \& J. Schot, Radical innovation as a multi-level process: introducing floating grain elevators in the port of Rotterdam, Technology and Culture, 46(1), 2005, pp. 51-76. 
39. D. C. Mowery \& N. Rosenberg, Paths of Innovation: Technological Change in 20th-Century America, (Cambridge, Cambridge University Press, 1998); p. 50.

40. C. McShane, Down the Asphalt Path: The Automobile and the American City (New York, Columbia University Press, 1994).

41. Ibid.

42. G. Mom, The Electric Vehicle: Technology and Expectations in the Automobile Age (Baltimore, MD, John Hopkins University Press, 2004).

43. C. Chant, The second industrial revolution and the rise of modern urban planning, in: D. Goodman \& C. Chant (Eds) European Cities and Technology: Industrial to Post-Industrial City (London, Routledge/The Open University, 1999), pp. 211-177.

44. McShane, op. cit., Ref. 40.

45. T. J. Pinch \& W. E. Bijker, The social construction of facts and artifacts: or how the sociology of science and the sociology of technology might benefit each other, Social Studies of Science, 14, 1984, pp. 399-441.

46. Mom, op. cit., Ref. 42.

47. McShane, op. cit., Ref. 40.

48. Ibid.

49. J. M. Faragher, M. J. Buhle, D. Czitrom \& S. H. Armitage, Out of Many: A History of the American People (New York, Prentice Hall, 1997).

50. McShane, op. cit., Ref. 40.

51. Ibid.

52. P. C. Baldwin, Domesticating the Street: The Reform of Public Space in Hartford, 1850-1930 (Chicago, Ohio State University Press, 1999).

53. C. McShane \& J. Tarr, The decline of the urban horse in American cities, The Journal of Transport History, 24(2), 2003, pp. 177-198.

54. McShane, op. cit., Ref. 40.

55. Ibid.

56. G. W. Hilton, Transport technology and the urban pattern, Journal of Contemporary History, 4, 1969, pp. $123-135$.

57. L. C. Hunter \& L. Bryant, The History of Industrial Power in the United States, 1780-1930, Vol. 3, The Transmission of Power (Cambridge, MA, The MIT Press, 1991).

58. Mom, op. cit., Ref. 42.

59. D. Nye, Electrifying America: Social Meanings of a New Technology (Cambridge, MA, The MIT Press, 1990).

60. Ibid.

61. Ibid.

62. Ibid.

63. Cited in McShane, op. cit., Ref. 40, p. 114.

64. Pinch \& Bijker, op. cit., Ref. 45.

65. Mom, op. cit., Ref. 42.

66. J. J. Flink, The Automobile Age (Cambridge, MA, The MIT Press, 1990).

67. Baldwin, op. cit., Ref. 52.

68. McShane, op. cit., Ref. 40.

69. N. Georgano, Bilen 1886-1930 (Gothenborg, Nordbok, 1985), p. 10.

70. Mom, op. cit., Ref. 42.

71. Ibid.

72. D. A. Kirsch, The electric car and the burden of history: studies in automotive systems rivalry in America, 1890-1996. PhD thesis, Stanford University, Department of History, 1996.

73. Mom, op. cit., Ref. 42.

74. Kirsch, op. cit., Ref. 72.

75. Mom, op. cit., Ref. 42.

76. K. Bürgle \& R. von Frankenberg, Autotypen Gestern und Heute (Stuttgart, Union Verlag, 1964).

77. Mom, op. cit., Ref. 42.

78. R. te Velde, Van technologische niche tot dominant regime: De verspreiding van de benzineauto 1859-1906 (Enschede, University of Twente, 1997).

79. Kirsch, op. cit., Ref. 72. 
80. H. Rao \& J. V. Singh, The construction of new paths: institution building in the early automobile and biotechnology industries, in: R. Garud \& P. Karnøe (Eds) Path Dependence and Creation (Mahwah, NJ, Lawrence Erlbaum, 2001), pp. 243-267.

81. Ibid.

82. Baldwin, op. cit., Ref. 52.

83. Faragher et al., op. cit., Ref. 49.

84. G. Mom \& D. A. Kirsch, Technologies in tension: horses, electric trucks, and the motorization of American cities, 1900-1925, Technology and Culture, 42, 2001, pp. 489-518.

85. Flink, op. cit., Ref. 66.

86. G. Yago, The Decline of Transit: Urban Transportation in German and U.S. Cities, 1900-1970 (Cambridge, Cambridge University Press, 1984).

87. Nye, op. cit., Ref. 59.

88. Flink, op. cit., Ref. 66.

89. Nye, op. cit., Ref. 59.

90. Mom, op. cit., Ref. 42.

91. McShane, op. cit., Ref. 40.

92. R. Kline \& T. Pinch, Users as agents of technological change: the social construction of the automobile in the rural United States, Technology and culture, 37(4), 1996, pp. 763-795.

93. W. J. Belasco, Americans on the Road: From Autocamp to Motel, 1910-1945 (Baltimore, The Johns Hopkins University Press, 1997)

94. P. J. Ling, America and the Automobile: Technology, Reform and Social Change, 1893-1923 (Manchester, Manchester University Press, 1990).

95. E. H. Wakefield, History of the Electric Automobile: Battery-only Powered Cars (Warrendale, PA, Society of Automotive Engineers, 1994).

96. J. B. Rae, Transportation technology and the problem of the city, Traffic Quarterly, 22, 1968, pp. 299-314.

97. Ling, op cit., Ref. 94.

98. Flink, op. cit., Ref. 66.

99. Ling, op cit., Ref. 94.

100. D. F. Davis, North American urban mass transit, 1890-1950: what if we thought about it as a type of technology?, History and Technology, 12, 1995, pp. 309-326.

101. Hilton, op. cit., Ref. 56.

102. Nye, op. cit., Ref. 59.

103. Baldwin, op. cit., Ref. 52.

104. McShane, op. cit., Ref. 40.

105. Mom, op. cit., Ref. 42.

106. McShane, op. cit., Ref. 40.

107. T. Lewis, Divided Highways: Building the Interstate Highways, Transforming American Life (Harmondsworth, UK, Penguin Books, 1999).

108. Flink, op. cit., Ref. 66.

109. Lewis, op. cit., Ref. 107.

110. Ibid.

111. Ibid.

112. For the notion that technology can act as catalyst for social change, see K. H. Sørensen, Social shaping on the move? On the policy relevance of the social shaping of technology perspective, in: K. H. Sørensen \& R. Williams (Eds) Shaping Technology, Guiding Policy: Concepts, Spaces and Tools (Cheltenham, Edward Elgar, 2002), pp. 19-35 (p. 22). 